Louisiana State University

LSU Digital Commons

Faculty Publications

Department of Geology and Geophysics

9-23-2009

\title{
Arc-continent collisions, sediment recycling and the maintenance of the continental crust
}

Peter D. Clift

University of Aberdeen

Hans Schouten

Woods Hole Oceanographic Institution

Paola Vannucchi

Università degli Studi di Firenze

Follow this and additional works at: https://digitalcommons.Isu.edu/geo_pubs

\section{Recommended Citation}

Clift, P., Schouten, H., \& Vannucchi, P. (2009). Arc-continent collisions, sediment recycling and the maintenance of the continental crust. Geological Society Special Publication, 318, 75-103. https://doi.org/ 10.1144/SP318.3

This Article is brought to you for free and open access by the Department of Geology and Geophysics at LSU Digital Commons. It has been accepted for inclusion in Faculty Publications by an authorized administrator of LSU Digital Commons. For more information, please contact ir@lsu.edu. 
17 Abstract: Subduction zones are both the source of most new continental crust and the 18 locations where crustal material is returned to the upper mantle. Globally the total amount of 19 continental crust and sediment subducted below forearcs currently lies close to 3.0 Armstrong 20 Units $\left(1 \mathrm{AU}=1 \mathrm{~km}^{3} / \mathrm{yr}\right)$, of which $1.65 \mathrm{AU}$ comprises subducted sediments and $1.33 \mathrm{AU}$

21 tectonically eroded forearc crust. This compares with average $\sim 0.4$ AU lost during 22 subduction of passive margins during Cenozoic continental collision. Individual margins may

\section{Arc-Continent Collisions, Sediment Recycling and the}

\section{Maintenance of the Continental Crust}

\author{
PETER ClLifT
}

School of Geosciences, University of Aberdeen, Meston Building, Kings College, Aberdeen, AB24 3UE, United Kingdom, and DFG-Research Centre Ocean Margins (RCOM), Universität Bremen, Klagenfurter Strasse, 28359 Bremen, Germany

\section{HANS SCHOUTEN}

Department of Geology and Geophysics, Woods Hole Oceanographic Institution, Woods Hole MA 02543, USA

\section{PAOLA VANNUCCHI}

Dipartimento di Scienze della Terra, Università deli Studi di Firenze, Via La Pira, 4, 50121 Firenze, Italy retreat in a wholesale, steady-state mode, or in a slower way involving the trenchward 
24 erosion of the forearc coupled with landward underplating, such as seen in the central and 25 northern Andean margins. Tephra records of magmatism evolution from Central America indicate pulses of recycling through the roots of the arc. While this arc is in a state of long-

27 term mass loss this is achieved in a discontinuous fashion via periods of slow tectonic erosion and even sediment accretion interrupted by catastrophic erosion events, likely caused by seamount subduction. Crustal losses into subduction zones must be balanced by arc magmatism and we estimate global average melt production rates to be 96 and 64

$31 \mathrm{~km} / \mathrm{m} . \mathrm{y} . / \mathrm{km}$ in oceanic and continental arc respectively. Key to maintaining the volume of the continental crust is the accretion of oceanic arcs to continental passive margins. Mass balancing across the Taiwan collision zones suggests that almost $90 \%$ of the colliding Luzon Arc crust is accreted to the margin of Asia in that region. Rates of exhumation and sediment recycling indicate the complete accretion process spans only 6-8 m.y. Subduction of sediment in both erosive and inefficient accretionary margins provides a mechanism for returning continental crust to the upper mantle. Sea level governs rates of continental erosion and thus sediment delivery to trenches, which in turn controls crustal thicknesses over $10^{7}-$ $10^{9}$ yrs. Tectonically thickened crust is reduced to normal values $(35-38 \mathrm{~km})$ over timescales of 100-200 Ma.

\section{Introduction}

The origins of the continental crust and the timing of its generation have been contentious issues in the Earth sciences for many years, largely revolving around arguments about whether the vast majority of the crust was generated during the Archaean (Armstrong \&

46 Harmon 1981; Bowring \& Housh 1995; Elliott et al. 1999; Goldstein et al. 1997), or whether

47 growth has been more gradual since that time (Albarede \& Brouxel 1987; Ellam \& 
Hawkesworth 1988; Moorbath 1978; O’Nions et al. 1979). More recently it has been suggested that continental crust has largely been generated in a series of rapid bursts of production between 1 and $3 \mathrm{Ga}$ that were linked to rapid convection events in the mantle (Hawkesworth \& Kemp 2006). In this model new upper crust is formed by differentiation from melt, leaving a large volume of dense residue, which may then be recycled back into the upper mantle via gravitational delamination. Generation of significant volumes of new crust does not appear to have been associated with areas of greatly thickened continental crust.

Although such an explanation implies that mantle plumes may have been fundamental in the generation of some early crust (e.g., West African and Arabian Shields (Boher et al. 1992; Stein \& Hofmann 1994)), most geochemical evidence instead indicates that subduction magmatism was the dominant source of new crustal material, especially during the Phanerozoic. Although continental crust is generally more andesitic than most modern arc magmatism (Rudnick 1995), a combination of geochemical and tectonic evidence indicates that active margins are likely the principle source of the continental crust (Barth et al. 2000; Dewey \& Windley 1981; Rudnick \& Fountain 1995; Taylor \& McLennan 1995). Exactly how new crust is generated and how rapidly this is recycled through the subduction zones is however still enigmatic. In this paper we examine the rates of mass recycling through subduction zones and assess the role of oceanic arc accretion in building and maintaining the continental crust. We specifically focus on the Phanerozoic when tectonic processes were the same as in modern plate tectonics. In this respect we do not try to understand how crust is recycled on the gigayear timescale, but rather how the volume of continental crust is maintained in the present tectonic regime. We do this by generating mass budgets for sediment and crustal flux to the global trench systems and comparing this with other possible mechanisms for crustal loss. 
Generation of the continental crust in the first place is only part of the process of how the modern continents were formed and is not the focus of this paper, which is the role that subduction processes play in the maintenance of the crust during Phanerozoic times. Some constraints on long-term crustal volumes have been gained through consideration of variations in global sea level. Because the volume of the ocean basins is controlled by the relative proportions of continental versus oceanic crust a progressive loss or gain of continental crust would necessarily result in long-term variations in the global sea level, assuming that the volume of water on the Earth's surface has remained roughly constant. Although sea level has varied in the geological past, the magnitude of the change over a variety of timescales is modest compared to the total depth of the ocean basins $(\sim 200 \mathrm{~m}$ compared to mostly 3-6 km; (Haq et al. 1987)) and there has been little net change since at least the start of the Phanerozoic. Schubert \& Reymer (1985) argued that because of the generally constant degree of continental freeboard (i.e., the average height of the continents above sea level) since the Precambrian, the continental crust must have remained close to constant volume since that time. In fact these authors argued that gradual cooling of the Earth has resulted in slight deepening of the ocean basins, implying slow crustal growth since that time. This slow growth model is supported by $\mathrm{Nd}$ isotopic evidence for continental extraction from the upper mantle (Jacobsen 1988), as well as new Hf-O oxygen isotope data from zircons in cratonic rocks (Hawkesworth \& Kemp 2006). Thus there appears to be a long-term balance between growth of new continental crust through arc magmatism and recycling of this crust back into the mantle via subduction zones.

\section{Mass Budgets for the Continental Crust}




\section{Subduction of Continental Crust}

For many years it was believed that large-scale subduction of continental material was impossible because of the density differences between continental crust, oceanic crust and the upper mantle. Nonetheless, if continental crust is generated at convergent margins then this requires some type of return flow to the upper mantle for the volume balance inferred from the freeboard argument to be maintained. While some have argued for delamination and loss of lower crustal blocks (Gao et al. 2004), others have suggested that large volumes of crust can be subducted during major collisional orogens (Hildebrand \& Bowring 1999; Johnson 2002).

An estimate of the degree of crustal recycling possible during continental collisions can be derived by considering the Earth's mountain belts formed by continent-continent and arc-continent (passive margin) collisions during the Cenozoic. In practice this means the Neotethyan belts of the Mediterranean, the Middle East and Himalayas, as well as Taiwan and the Ryukyu Arc, northern Borneo and the Australia-Papua New Guinea region. In total these sum to almost $16,000 \mathrm{~km}$ of margin (Table 1). We assume a gradual thinning of the crust across these margins due to the progressive extension prior to break-up, and thus an average crustal thickness of $18 \mathrm{~km}$ (half normal continental (Christensen \& Mooney 1995)). We further assume that like the modern oceans around $50 \%$ of the subducted margins were volcanic (50 km wide continent-ocean transition (COT)) and the remainder non-volcanic (150 km wide COT). The sedimentary cover to colliding margins is usually imbricated into the orogen but apart of small occurrences of high-grade rock subducted and then re-exhumed to the surface (e.g., (Leech \& Stockli 2000; Ratschbacher et al. 2000) the crystalline crust is potentially lost to the mantle. We calculate that around $28 \times 10^{6} \mathrm{~km}^{3}$ have been subducted since the Mesozoic, resulting in a long-term average of 0.43 Armstrong Units ( $1 \mathrm{AU}=1$ 
$120 \mathrm{~km}^{3} / \mathrm{yr}$ ). Table 1 shows the basis of this estimate, involving the subduction of around $2.8 \mathrm{x}$

$12110^{9} \mathrm{~km}^{3}$ of passive margin crust since $65 \mathrm{Ma}$. If we assume that all the subducted margins were non-volcanic then the total subducted would increase to $4.2 \times 10^{9} \mathrm{~km}^{3}$ and the long-term recycling rate to $0.65 \mathrm{AU}$.

\section{Mechanisms of Subduction Erosion}

This study focuses on quantifying the processes by which crust is returned to the mantle via subduction zones. von Huene \& Scholl (1991) synthesized a series of earlier studies and proposed that large volumes of sediment and forearc crust, are being subducted in modern trenches. The concept that convergent margins not only accrete trench sediments in

130 forearc prisms (accretionary wedges) but also allow deep subduction of continental material 131 within a "subduction channel" was pioneering. Tectonic erosion of some plate margins had been recognized before (Hilde 1983; Miller 1970; Murauchi 1971; Scholl et al. 1977), but von Huene \& Scholl (1991)'s idea that this was a process common in many of the Earth's subduction zones helped geologists reconcile the apparent mis-match between a stable crustal volume and the ongoing arc magmatism. Their study helped properly establish the fact that there are two end member types of active margin, accretionary and erosive, and that the latter are common, especially in the Circum-Pacific region (Figs. 1 and 2).

It is still not yet agreed quite how tectonic erosion is accomplished, with competing models suggesting mechanical abrasion by fault blocks on the underside of the subducting

140 plate acting like a "buzz saw" (Hilde 1983), while others emphasize the importance of

141 subducting aseismic ridges in abrading material from the forearc (Clift \& MacLeod 1999;

142 Clift et al. 2003a; Ranero \& von Huene 2000; Vannucchi et al. 2003; von Huene \& Ranero

143 2003). Alternatively, the importance of fluids in this process was first suggested by von 
144 Huene \& Lee (1982). In this type of model water expelled from the subducting plate causes

145 hydrofracturing and disintegration of the base of the overlying forearc (Platt 1986; von Huene 146 et al. 2004). The disrupted fragments would then be released into the subduction channel and

147 transported to depth, either to the roots of the volcanic arc or even to the upper mantle.

148 Evidence from the first recognized palaeo-subduction channel in the Italian Apennines shows

149 that material was being returned to the deep Earth via a 500-m-wide zone and that tectonic

150 erosion of the forearc wedge was occurring both on its underside and frontal "toe" region

151 (Vannucchi et al. 2008).

Clift \& Vannucchi (2004) used large-scale, long duration (>10 m.y.) estimates of

153 forearc mass change to improve the estimated rates of accretion or mass loss in all convergent

154 margins. They predicted that around 3.6 AU were being subducted globally, rather higher

155 than the 1.6 AU estimated by von Huene \& Scholl (1991). They recorded 57\% of modern trenches as being in a long-term tectonically erosive mode (Fig. 1) and noted that there was a correlation between margins where there was less than $1 \mathrm{~km}$ of sediment in the trench and tectonic erosion. In contrast, margins with $>1 \mathrm{~km}$ of trench sediment were sites of net accretion (Fig. 3). Because the last 2-4 m.y. are generally recognized as being a period of

160 faster than normal continental surface erosion (Zhang et al. 2001), and presumably faster 161 clastic trench sedimentation, it seems likely that $1 \mathrm{~km}$ is an over-estimate of this threshold over long periods of geologic time. This is because the Plio-Pleistocene pulse of faster sediment supply would not have had sufficient time to impact the long term growth rates of

164 convergent margins. $400 \mathrm{~m}$ is however an absolute lower bound to the accretionary threshold

165 because this is the thickness of purely pelagic sediment found in many trenches in both the eastern and western Pacific Ocean, where there are no clastic trench sediments and where 
168 glacial cycles the Earth's subduction systems are likely to now be in a particularly

169 accretionary mode, and that prior to Northern Hemispheric Glaciation tectonic erosion would 170 have been even more dominant.

171 An important feature of accretionary margins is that while they are regions of net

172 continental growth this does not mean that no continental crust is being recycled to the

173 mantle in these margins (von Huene \& Scholl 1991). Indeed, over long periods of geologic

174 time the proportion of sediment reaching the trench and preserved in accretionary margins 175 averages only $\sim 19 \%$ globally (Clift \& Vannucchi 2004). It is not clear whether this is because 176 subduction accretion is a very inefficient process, or because even accretionary margins

177 suffer phases of tectonic erosion, perhaps triggered by subduction of seamounts or aseismic 178 ridges. Drilling and modelling of the accretionary wedge in the Nankai Trough of SW Japan

179 indicates that décollement in the trench sediment pile preferentially occurs near the base of 180 the coarser grained trench sands, while the finer grained hemipelagic sediments below seem 181 to be underthrusted, at least below the toe region of the wedge (Le Pichon et al. 1993). This 182 means that a significant proportion of the trench sediment column is underthrust at that, and 183 presumably most other margins, even when no ridge or seamount collision is occurring.

184 Mass loss rates increase during subduction of aseismic ridges. 3D seismic reflection data has 185 shown that such ridges have resulted in temporary periods of tectonic erosion, followed by a 186 reversion to more efficient sediment accretion (Bangs et al. 2006).

Non-Steady State Tectonic Erosion

190 Observations of shallow water or subaerial sedimentary rocks now found in trenches 191 indicate long-term crustal loss over periods of $>10^{7} \mathrm{yr}$, but do not preclude shorter intervals 
192 of net accretion. Conversely margins in a state of long-term net accretion may also

193 experience periods of tectonic erosion, usually linked to the passage of seamounts or other 194 topographic features on the subducting plate. Some estimates of the time scale of these 195 alternations can be derived from reconstructions of vertical tectonic motions. Melnick \& 196 Echtler (2006) used seismic data from the southern Andean margin to show that the marine

197 forearc in this area has experienced basin inversion and uplift since the Pliocene, reversing a 198 long-term trend to subsidence and crustal loss. In that study inversion was attributed to the 199 increased sediment flux to the trench due to faster continental erosion driven by the glacial200 interglacial cycles. Increased sediment flux was inferred to lubricate the base of the forearc 201 wedge, reducing friction along that contact and driving a readjustment of the critical angle of 202 the wedge. In this respect the model followed the suggestion by Lamb \& Davis (2003) that 203 reduced sediment flux to the central Andean trench increased coupling between over-riding 204 and subducting plates and triggered uplift of the main Andean ranges. If this were true then the total crustal flux to the upper mantle would increase as continental erosion increased.

207 constrained thanks to linked onshore-offshore data sets. The Andean margin of Peru and 208 northern Chile provides a good example of an active margin in a state of long-term mass loss 209 (von Huene \& Ranero 2003). About $250 \mathrm{~km}$ of crust is estimated to have been lost from the 210 western edge of South America in northern Chile and southern Peru since 150 Ma (Rutland 211 1971; Scheuber \& Reutter 1992; Stern 2004), with as much as $30 \mathrm{~km}$ of this loss occurring 212 since $10 \mathrm{Ma}$ (Laursen et al. 2002). A landward step of $30-40 \mathrm{~km}$ in the trench axis north of 213 the Juan Fernandez Ridge since 10 Ma resulted in trench retreat rate estimates of about 3.0 $214 \mathrm{~km} / \mathrm{m}$.y. during the Miocene-Recent, with similar values estimated from offshore Mejillones 215 (von Huene \& Ranero 2003). In such an environment forearc subsidence is predicted and has 
216 been observed in seismic and drilling data (Clift et al. 2003a; Laursen et al. 2002; von Huene

217 \& Ranero 2003)(Fig. 4), with temporary periods of uplift at the point where aseismic ridges 218 are in collision with the trench.

219 Comparison of onshore and offshore data in the central Andes however indicates that 220 the margin is not in a continuous state of wholesale landward retreat. Sedimentary evidence 221 from basins exposed along the coast demonstrates that the shoreline has been relatively 222 stationary since $16 \mathrm{Ma}$ and has not migrated inshore, as might be expected. Moreover, the exposure of these basins and the presence of marine terraces over long stretches of the margin (Fig. 5) point to recent uplift since at least the start of the Pleistocene ( 1.8 Ma). Subsidence analysis backstripping methods were applied by Clift \& Hartley (2007) to measured sections from these onshore coastal basins in order to isolate the tectonically driven subsidence of the basement, after correcting for sediment loading and sea-level variability. Although rates of tectonic erosion and subsidence are much higher close to the trench the continental basins are useful because the shallow shelf depths involved provide relatively high precision constraints on vertical motions compared to deep-water trench or slope sediments.

Figure 6 shows the results of these analyses for the Pisco, Salinas, Mejillones, Caldera and Carrizalillo Basins. What is remarkable is that all these basins show a coherent, albeit slow basement subsidence, as might be predicted for a tectonically erosive margin, since 16 $\mathrm{Ma}$, at the same time as the trench is known to retreat landwards and the marine forearc to subside (Fig. 4). However, like the southern Andean basins (Melnick \& Echtler 2006) they also all show a late Pliocene unconformity, followed by terrestrial and coastal sedimentation preserved in a series of Pleistocene terraces. Although uplift can be generated by flexure in the footwall of normal faults, this is necessarily localized. However, the regional style of uplift observed along long stretches of the Andean coast and in the form of extensive 
240 terracing across a zone $5-10 \mathrm{~km}$ wide requires regional crustal thickening. This is most likely 241 caused by subduction accretion and basal underplating of the forearc crust. The observation 242 of active extensional faulting in much of the forearc precludes thickening by horizontal compression and thrust faulting. The central Andean margin experiences tectonic erosion but 244 instead of the wholesale retreat of the plate margin the forearc is constrained to steepen since $24516 \mathrm{Ma}$ (Fig. 7A) and then experience underplating since $2 \mathrm{Ma}$. As a result mass flow rates are much lower here than would be predicted for a steady-state erosive margin.

It is tempting to relate the Pleistocene shift to limited accretion under much of the terrestrial forearc due faster trench sedimentation forced by climatic changes during the onset of Northern Hemispheric glaciation, much, as suggested for the southern Andes (Melnick \& Echtler 2006). However, this model does not hold up in the central Andes where there are effectively no trench clastic sediments even today, reflecting the very arid climate of the continental interior. We conclude that the recent change in trench tectonics in the Andes is likely driven by a tectonic change in the way that the Pacific and South American plates interact.

Analysis of seismic and drilling data from the Andean forearc offshore the Lima Basin (Figs. 4 and 5) also suggests that tectonic erosion is a temporally and spatially 257 discontinuous process. Backstripping analysis of Ocean Drilling Program (ODP) Site 682 on the trench slope has been used to demonstrate long-term mass loss (Fig. 6)(Clift et al. 2003a), accelerating after the collision of that part of the trench with the aseismic Nazca Ridge. Like

260 the onshore basins to the south ODP Site 679, also located in the Lima Basin but in shelf 261 water depths, shows slow basement subsidence, with temporary uplift during passage of the 262 Nazca Ridge along this part of the trench at 11-4 Ma (Fig. 5)(Hampel 2002). However, 263 interpretation of seismic lines across the forearc (Clift et al. 2003a)(Fig. 4) shows that the 
264 trenchward part of Lima Basin has been uplifted $>500$ m relative to the landward portions of

265 the basin since the end of the Pliocene. This suggests Pleistocene underplating of the outer 266 part of the forearc, where typically subduction erosion is most rapid. Uplift is consistent with

267 the observation of a small accretionary complex at the foot of the trench slope in this region 268 (Fig. 4A). The Aleutian forearc provides an additional example of this kind of process 269 because although a significant accretionary wedge is developed at the trench the mid forearc 270 is dominated by a deep basin whose subsidence can only be explained by major basal erosion 271 of the wedge (Ryan \& Scholl 1993; Wells et al. 2003). Clearly accretion and erosion are spatially and temporally variable, even on a single length of margin.

273

\section{Geochemical Evidence for Temporal Variations}

Changes in the rates of sediment subduction and forearc tectonic erosion affect forearc vertical motions but must also impact the chemistry of arc volcanism. Geochemical evidence exists in Central America to suggest variations on the 1-4 m.y. timescale in tectonic erosion, as well as related but independent changes in sediment subduction. In Costa Rica two different views of mass flux have been proposed. Tectonicists have shown that the margin and trench slope are in a state of long-term subsidence and presumed mass loss due to subduction erosion (Meschede et al. 1999; Vannucchi et al. 2001; Vannucchi et al. 2003).

282 Geochemical data from the active arc (e.g., ${ }^{10} \mathrm{Be}$ isotopes) indicates that the sedimentary cover in the modern trench cannot presently be contributing significantly to petrogenesis.

284 This has been interpreted to imply that either the sediment is being off-scraped and accreted 285 to the margin (Morris et al. 2002; Valentine et al. 1997), or that tectonic subduction erosion 286 is adding large volumes of additional material to the subduction channel so that the sedimentary signal to the arc magma is strongly diluted (Vannucchi et al. 2003). Early 
geophysical surveys had proposed that the Costa Rican forearc was largely comprised of an

289 accretionary wedge (Shipley et al. 1992), yet drilling of the region by ODP Leg 170

290 demonstrated that in fact the slope was formed by an extension of the onshore igneous

291 Nicoya Complex, mantled by a relatively thin sedimentary apron of mass wasted continental

292 detritus and hemipelagic sediments (Kimura et al. 1997). Although the ODP drilling ruled out

293 the possibility of much accretion of oceanic sediments at the toe of the forearc wedge during

294 the recent geologic past, drilling was not able to show whether sediments have been transferred to the overriding plate by underplating at greater depths. Clearly competing models advocating accretion and erosion cannot both be correct, at least over the same time scales.

Study of the tephras deposited offshore the Nicoya Peninsula, Costa Rica, offer a possible explanation to these contradictory lines of evidence. Tephras can be used to reconstruct the magmatic evolution of the adjacent arc (the prevailing winds blow directly offshore) because the isotopic composition of the arc magmas (from which the tephras are derived) reflects the degree of sediment and forearc recycling in the subduction zone. As a result the isotope geochemistry of the tephras can be used to quantify the degree of recycling at the time of their deposition. The cause of the tectonic erosion cannot be constrained from the tephras alone, but is inferred in this case from modern geophysical data that indicate this process to be the primary cause of erosion in Costa Rica (Ranero \& von Huene 2000). essentially unaltered, allowing them to be used to trace the temporal evolution of the onshore

309 volcanic arc (Clift et al. 2005a). Trace element characteristics were compared to the active 310 arc and a generally good fit was recognized between the tephra and the Costa Rican part of 311 the central American volcanic zone, a match that is possible because of the major along strike 
312 variability noted between Costa Rica, Guatemala and Nicaragua (Carr et al. 2003; Leeman et

313 al. 1994; Patino et al. 2000; Reagan et al. 1994). Clift et al. (2005a) employed Li and Nd

314 isotopes to quantify the influence of sediment subduction and tectonic erosion on arc

315 petrogenesis, an approach that was possible because of the different isotopic characteristics of

316 trench sediments, the Nicoya Complex forearc basement and the altered oceanic crust

317 entering the trench (Fig. 8A). These end members allow the relative contributions of these

318 sources to be resolved and unmixed. Figure 8B shows that at $1.45 \mathrm{Ma}$ an unusual tephra was

319 deposited showing an anomalous composition in $\mathrm{Nd}$ isotopes (i.e., relatively negative $\varepsilon_{\mathrm{Nd}}$ ).

320 This composition departs sharply from that of the nearest Costa Rican arc volcano, Arenal, as

321 well as the other tephra in the stratigraphy, thus indicating a short-lived pulse of enhanced

322 continental sediment subduction. The Li isotope composition also shows strong temporal

323 variability, with high $\delta^{7} \mathrm{Li}$ values being achieved at and for around $0.5 \mathrm{~m} . \mathrm{y}$. after the $\varepsilon_{\mathrm{Nd}}$

324 spike. Subsequently $\delta^{7} \mathrm{Li}$ reduced to low values at the present day. These trends were 325 interpreted to show that both sediment subduction and forearc erosion are currently at low

326 levels, as inferred from study of the volcanoes themselves, but that this pattern is atypical of

327 the recent geologic past. The patterns of isotope evolution may reflect collision of a seamount

328 with the trench before $1.45 \mathrm{Ma}$, driving subduction of a sediment wedge formed there, and

329 subsequently increasing erosion and subduction of forearc materials. The whole cycle from

330 accretion to erosion and back to accretion appears to span $<2$ m.y.

$332 \quad$ Rates of Mass Recycling

334 Rates of Sediment and Crustal Subduction 
Table 2 presents revised estimates of the rates of sediment accretion, tectonic erosion

336 and arc magmatism for global active margins based on the study of Clift \& Vannucchi 337 (2004), but updated with new constraints for some crucial margins. These figures indicate 338 less crustal subduction than proposed in the earlier study, mostly as a result of reduced 339 estimates for tectonic erosion in the Andean margin of Peru and northern Chile (Clift \& 340 Hartley 2007). Even so, we estimate that worldwide total continental mass subduction lies 341 close to 3.0 AU, compared to around 3.6 AU in the synthesis of Clift \& Vannucchi (2004), but still more than the 1.6 AU of von Huene \& Scholl (1991). This value is almost an order of magnitude more than the $0.4 \mathrm{AU}$ estimate for recycling of subducted passive margins in orogenic belts (Table 3).

The total amount of sediment being subducted at the world's trenches is relatively well constrained, because trench sediment thicknesses and convergence rates are relatively well known. In contrast, rates of subduction erosion of forearc crust are less well documented and appear to be quite variable in time. Of the total continental crust subducted globally at least as deeply as the magmatic roots of the arc systems we estimate that 1.65 AU comprise subducted sediments, with 1.33 AU of eroded forearc. Thus the latitude for error in the total estimate principally lies in the $1.33 \mathrm{AU}$ of tectonic erosion. Regions where this value is not well known are themselves becoming scarcer. While the degree of tectonic erosion may change due to further research we believe that the amount of change in the total sum cannot be too large and that the $3.0 \mathrm{AU}$ recycling rate is unlikely to be more than $\sim 20 \%$ in error.

Rates of trench retreat are the most common source of tectonic erosion estimates and many are based on the identification of terrestrial or shallow-water sediments overlying basement on the trench slope of modern systems (Clift \& MacLeod 1999; Laursen et al. 
1982). Rates of loss are then calculated based on the distance between the modern location of

360 the shallow water sedimentary rock and the location where similar facies sediments are now

361 being deposited in the modern forearc. Rates of trench retreat are then derived by dividing

362 this across-strike distance by the age of the sedimentary rock. Trench retreat rates in turn can

363 be converted to rates of crustal volume loss if the thickness of the forearc crust is known and

364 if the mode of subduction erosion is assumed. In the simplest and most conservative model

365 trench retreat occurs along a margin in which the geometry remains effectively constant

366 through time. Figure 7B shows that in this case a retreat of any given distance must involve

367 loss of a complete crustal section of this width, since the forearc wedge itself remains

368 constant. However, over short time spans tectonic erosion can result in steepening of the

369 forearc slope and a retreat of the trench with much lower total volumes of crustal subduction

370 (Clift \& Hartley 2007).

371

372

Rates of Arc Magmatism

373

Although short-term variations in mass flux through any given subduction zone can

374 be driven by ridge and seamount collisions, or even climatically induced changes in trench

375 sedimentation the recognition that some margins have been in a long-term state of erosion or

376 accretion allows mass budgets for plate margins to be made over periods of geologic time $10^{7}$

$377 \mathrm{yr}$ or longer. As argued above, this loss has been balanced by arc magmatism, assuming a

378 relatively constant volume of water at the Earth's surface and in the presence of a stable sea

379 level. Although Clift \& Vannucchi (2004) calculated that this rate of production averaged

$380 \sim 90 \mathrm{~km}^{3} / \mathrm{m} . \mathrm{y} . / \mathrm{km}$ of trench this figure can now be reduced in light of the much lower crustal

381 recycling rates for the Central and Northern Andes (Clift \& Hartley 2007). Because of the

382 length of the Andean margin and the thickness of the continental crust here this adjustment 
makes a significant difference to the rate of loss and brings the global average rate of arc

384 production down to $74 \mathrm{~km}^{3} / \mathrm{m} . \mathrm{y} . / \mathrm{km}$. The rate of recycling is likely to change as more geophysical information because available from the long stretches of active margin that have not yet been targetted for investigation.

Determining if this value is realistic or not can be difficult because rates of melt production under continental arcs are hard to determine. This is because only a small fraction of the melt is actually erupted, while most is intruded into or underplated on to the base of the crust. This is typically hard to resolve seismically and even harder to date. The situation is easier in oceanic arcs, where the whole crustal section is generated by subduction magmatism. If the age of subduction initiation is known then an average rate of production can be calculated. Holbrook et al. (1999) estimated long-term magmatic growth rates of 55$82 \mathrm{~km}^{3} / \mathrm{my}$ per $\mathrm{km}$ of margin for the Aleutians, while Suyehiro et al. (1996) indicated longterm average accretion rates of $66 \mathrm{~km}^{3} /$ my per $\mathrm{km}$ of margin in the Izu Arc. Both these estimates do not account for the gradual loss of crust by subduction erosion, meaning that the true estimates of magmatic output for these arcs would be higher. However, it should also be recognized that most of the forearc crust in the Tonga, Mariana, Izu, and Bonin arcs is boninitic and produced rapidly after the initiation of subduction, $\sim 45 \mathrm{Ma}$ (Bloomer \&

400 Hawkins 1987; Stern \& Bloomer 1992). This means that the steady-state average rate of crustal production is likely somewhat below the long-term average derived from seismic measurements. We conclude that the inferred rate of long-term crustal productivity is within error of the best constrained arc magmatic production rates.

Melting in continental active margins necessarily adds new material directly to the continental crustal mass, but the same is not necessarily true for oceanic arcs. Because these are built on oceanic lithosphere this material may be subducted when the arc collides with 
407 another trench system along with the lithosphere on which it is built. If oceanic arc crust is

408 not accreted to continental margins during arc-continental collision then the continental mass

409 balance would be disturbed and this subducted arc crust would need to be compensated for by

410 greater production in continental arcs. This seems unlikely to be occurring because

411 continental arc production is typically estimated to be lower than that in oceanic arcs (Plank

412 \& Langmuir 1988). For example, Atherton \& Petford (1996) estimated production in the

413 Andes be only $8 \mathrm{~km}^{3} / \mathrm{m} . \mathrm{y} . / \mathrm{km}$. Although oceanic arcs account for only $31 \%$ of the total active

414 margins in the world our mass budget suggests that 40\% (1.2 AU) of global arc melt

415 production occurs along these margins. We estimate global average melt production rates to

416 be 96 and $64 \mathrm{~km}^{3} / \mathrm{m} . \mathrm{y} . / \mathrm{km}$ in oceanic and continental arc respectively. If all the production

417 needed to balance global subduction losses (3.0 AU) occurred only in the continental arcs

418 then the average rate of melt production in these settings would increase to an unrealistic 106

$419 \mathrm{~km} / \mathrm{m} . \mathrm{y} . / \mathrm{km}$. Thus efficient accretion of oceanic arc crust is important to the maintenance of

420 the continental crust, but whether this really occurs or not is open to question. It is

421 noteworthy that there are very few accreted oceanic island arc sections on Earth. Kohistan

422 (Himalayas (Khan et al. 1997; Treloar et al. 1996)), Alisitos (Baja California (Busby et al.

423 2006)) and Talkeetna (Alaska (DeBari \& Coleman 1989)) are noteworthy for being the most

424 complete, while many other examples are small and fragmentary, typically comprising only

425 lavas and volcaniclastic sedimentary rocks. The fate of the oceanic Luzon Arc in the classic

426 arc-continent collision zone of Taiwan is unclear as only a fragment can be seen in the

427 Coastal Ranges. Here we explore its accretion.

428

429

Arc Accretion as a Steady-State Process 
If arc accretion is to be understood as an integral part of the plate tectonic cycle, and as a key process in maintaining the continental crustal volume then the classic example of 432 Taiwan may be used to quantify the processes that occur when an oceanic arc (Luzon) collides with a passive continental margin (Chemenda et al. 1997; Suppe 1981). This type of collision must be relatively common within the life span of the Earth and it has been suggested that it is this process that transforms mafic, depleted arc crust into more siliceous, enriched continental crust (Draut et al. 2002). In this scenario high silica, LREE-enriched magmas are injected into the mafic oceanic arc crust as it collides with a passive continental margin. At the same time the mafic/ultramafic lower crust may be subducted along with the mantle lithosphere on which the arc is constructed, made possible by detachment in the weak middle crust.

Arcs may also be accreted to active continental margins and there are examples (e.g., Dras-Kohistan and Talkeetna in southern Alaska) where a complete oceanic crustal section has been transferred to a continental margin when subduction eliminates the oceanic crust between the two arc of the same subduction polarity (Aitchison et al. 2000; Clift et al. 2005b; DeBari \& Coleman 1989; Treloar et al. 1996). In both these examples the Moho itself can be observed in the field and there is little doubt that crustal accretion has been efficient.

447 However, the fate of the arc crust during arc-passive margin collision is less clear because such collisions result in the formation of active continental margins following subduction polarity reversal, so that the oceanic plate on which the oceanic arc was constructed is then subducted (Casey \& Dewey 1984).

In Taiwan the topographic massif of the North Luzon Arc disappears beneath the SE

452 flank of Taiwan and it is unclear how much arc crust is accreted because the Taiwan ranges 453 themselves expose thick sequences of deformed and metamorphosed Chinese passive margin 
454 sedimentary rocks, with only small scattered exposures of volcanic and volcaniclastic rocks

455 found in the eastern Coastal Ranges (Lundberg et al. 1997; Song \& Lo 2002). In this study 456 we attempt to mass balance the collision in order to assess the efficiency of the accretion

457 process. In doing so we model the collision of Luzon and China as being a steady-state 458 process that is migrating progressively to the SW with time and which started to the NE of 459 the present collision point at some point in the geologic past. We note that some models 460 propose initial Luzon collision to have only initiated around 6-9 Ma, effectively just to the east of the present collision zone, with a transform boundary between the Manila and Ryukyu Trenches prior to collision (Huang et al. 2000; Huang et al. 2006; Sibuet \& Hsu 1997; Suppe 1984). Here we favour a more steady-state collision that may have started much earlier and potentially a long way to the east on modern Taiwan (Clift et al. 2003c; Suppe 1984; Teng 1990).

Migration of the arc collision along the margin is then controlled by the speed and obliquity of convergence (Fig. 9). In this scenario along strike variability in the orogen represents different phases in the arc accretion process, with a pre-collisional Luzon arc south of Taiwan, peak collision in the centre of the island and post-collisional orogenic collapse and subduction polarity reversal to the NE of Taiwan. In effect the Luzon arc can be considered to act in a rigid fashion like a snow plough deforming the passive margin of China into an accretionary stack, which then collapsed into the newly formed Ryukyu Trench as the collision point migrated to the SW along the margin (Fig. 10). In this scenario the collapsed orogen comprises slices of Chinese passive margin and the accreted Luzon arc crust, which are then overlain in the Okinawa Trough by sediments eroded from the migrating orogen. 
478 Fortunately gravity and seismology data allow the large-scale crustal structure of the orogen

479 to be constrained, especially the depth and geometry of the main detachment on which the 480 thrust sheets of passive margin sedimentary rock are carried (Fig. 11)(Carena et al. 2002;

481 Chen et al. 2004; Lee et al. 2002). Similarly, the depth and width of the foreland basin is well 482 characterized by seismic and gravity data (Lin et al. 2003). Combined gravity, seismic 483 reflection and refraction surveys constrain the crustal structure in the western Okinawa 484 Trough and Ryukyu Arc, where Moho depths appear to be 25 and $30 \mathrm{~km}$ respectively 485 (Kodaira et al. 1996; Wang et al. 2004). The volume of crust in the colliding arc is less well constrained, but the regional structure across the arc and forearc is known from seismic surveys (Hayes \& Lewis 1984), and the crustal thickness of the igneous arc can be estimated at reaching a maximum of $\sim 25 \mathrm{~km}$ from gravity data and comparison with seismic data from other oceanic island arcs (Holbrook et al. 1999; Suyehiro et al. 1996). Sediment volumes on the northern margin of the South China Sea are best characterized from the Pearl River Mouth Basin to the SW of Taiwan where abundant seismic reflection and drilling data provide a good estimate of the total amount of sediment available to be imbricated into the thrust sheets (Clift et al. 2004). Our estimates of the crustal volumes are derived from the sections shown in Figure 11 and are listed in Table 4.

By summing the volume of the crustal blocks at each stage of the collision we are able to assess how much material might be subducted during the collision process. This budget is shown graphically in Figure 12. What is most striking is that the great crustal thickness under Taiwan can only be accounted for if the meta-sedimentary thrust sheets that 499 characterize the exposed ranges are underlain by a great thickness of arc crust. The total 500 volume of sediment on the Chinese margin, together with recycled sediments in the accretionary complex west of the Luzon Arc do not come close to explaining the volume of 
502 material lying above the basal detachment in the orogen. Although the cross section could be

503 drawn in alternative ways that would change the precise balance between crustal blocks the 504 need to accrete most of the Luzon Arc crust to the Chinese margin to make the sections 505 balance is a common feature of all the reasonable reconstructions. Reducing the volume of 506 accreted arc crust requires that this volume be made up by meta-sedimentary thrust sheets, 507 yet the total volume of sediment on the Chinese margin or in the Manila Accretionary 508 Complex is insufficient to account for this. It is this relative lack of material from which to 509 form the Central Range thrust sheets, together with a relatively voluminous colliding arc that

510 requires the boundary between arc and orogen to dip westwards under the Central Ranges

511 from the Longitudinal Valley. If this boundary is close to vertical then this would require the

512 volume of the thrust sheets to be much greater than all the sediments on the Chinese passive 513 margin and Manila Accretionary Complex from which the range is apparently built. A west514 dipping thrust is nonetheless consistent with the structure of the eastern Central Ranges.

In our estimate $\sim 87 \%$ of the incoming arc crust is accreted. In addition, some

516 sedimentary material appears to be lost, likely through erosion and recycling back into the

517 pre-collisional accretionary complex, in which only part of the incoming section is

518 imbricated, while some is lost to depth below the arc. The collapse thrust sheets and accreted

519 Luzon arc crust is then required to form the basement to the new Ryukyu Arc. The deformed 520 edge of the Chinese margin is marked by the Taiwan-Sinzi Folded Belt (Fig. 9), located 521 landward of the Okinawa Trough. This means that the Okinawa Trough itself and the arc 522 ridge must be comprised of accreted sediments and arc crust. 
The degree of sediment recycling during arc accretion can be estimated through a

526 similar mass balancing exercise and through understanding of the rates of rock uplift and 527 exhumation along the strike of Taiwan. Regional trends in rock uplift rates can be determined 528 from the current elevations and the age of the collision, together with estimates for the 529 amount of exhumation derived from the metamorphic grade and fission-track data (Dadson et 530 al. 2003; Fuller et al. 2006; Liu et al. 2000; Tsao et al. 1992; Willett et al. 2003). Although in 531 some locations modern rates of uplift have been determined by dating terraces (Peng et al. 1977; Vita-Finzi \& Lin 1998) these are necessarily limited to the coastal regions, mostly in the Coastal Ranges of eastern Taiwan and are not useful for estimating rates of the main accretionary stack. We follow Fuller et al. (2006) in placing peak erosion rates at $8 \mathrm{~mm} / \mathrm{yr}$., falling to $6 \mathrm{~mm} / \mathrm{yr}$. over much of the Central Ranges. These values are consistent with the suspended sediment load calculations of Fuller et al. (2003) that predicted rates of 2.2-8.3 mm/yr. Similarly, Dadson et al. (2003) used data from river gauging stations to yield an average Central Range erosion rate of $\sim 6 \mathrm{~mm} / \mathrm{yr}$. rates of rock uplift are highest during the most intense period of collisional compression

541 between Luzon and China; these are partly balanced by erosion driven largely by 542 precipitation, but also by tectonic extension (Crespi et al. 1996; Teng et al. 2000).

543 Exhumation and vertical uplift rates decrease rapidly toward the northern end of the Central 544 Ranges, and especially around the Ilan Basin (Fig. 13), although active motion along a detachment reversing the Lishan Fault causes increased exhumation in the Hsüehshan Range.

546 Because the rates of exhumation are known from the fission track analysis the total amount of

547 exhumation can be calculated by knowing the duration of the collision, i.e., the speed of arc 548 migration. We show three possible models for sediment accretion and erosion in Figure 14, 
549 based on collision starting at $5 \mathrm{Ma}, 4 \mathrm{Ma}$ and $3 \mathrm{Ma}$. The $5 \mathrm{Ma}$ collision age would suggest $550 \sim 20 \mathrm{~km}$ of exhumation, somewhat more than the upper greenschist facies rocks that 551 characterize the Central Ranges $(\sim 12-15 \mathrm{~km}$ burial), yet this apparent mis-match does not 552 preclude an earlier collision because of the continuous nature in which passive margin 553 sediments may be added to the thrust stack, and recycled at shallower levels, so that while 20

$554 \mathrm{~km}$ of erosion occurs this does not result in the progressive unroofing of deeper buried rocks 555 (Willett et al. 1993) (Fig. 15).

556 The 5 Ma collision age is favoured by most recent syntheses (Huang et al. 2006), typically based on the ages of cooling, but also on the age of syn-collisional sedimentary rocks exposed in the Coastal Ranges. The Shuilien Conglomerate is dated to start deposition around $3 \mathrm{Ma}$ (Chi et al. 1981), yet even this can be considered a minimum age because of the potential for along-strike transport from the location of erosion to the depositional basin.

The most striking result of the sedimentary mass balance is that the volume of metasedimentary rocks together with the eroded volumes when compared with the total volumes of possible sediment source seem to require that the rocks now exposed in northern Taiwan, 564 were uplifted and became emergent in a palaeo-southern Taiwan no later than $4 \mathrm{Ma}$. There is 565 simply insufficient sediment on the northern margin of the South China Sea to account for the orogen and its eroded sediment if uplift and subaerial erosion in the current area of Taiwan started at $5 \mathrm{Ma}$ or before. This means that the speed of collision requires only $4 \mathrm{~m} . \mathrm{y}$. for a rock to travel from the southern coast of Taiwan to the collapsing mountains around the Ilan Plain. While some of the eroded sediment is transported into the Okinawa Trough the bulk is recycled back through the foreland basin and south into the Luzon Trench. Because the distal passive margin begins to collide with the Manila Trench south of southern Taiwan we estimate 6-8 m.y. for the duration of the entire accretionary process. 


\section{Erosional Control on Crustal Recycling and Thickness}

The image we have of the global subduction system is that it both generates new crust principally via arc magmatism and to a lesser extent via subduction accretion, and also returns crustal material to the mantle in tectonically erosive and accretionary active margins.

578 Trench sediment thickness is the primary control on whether a margin is in a state of long-

579 term accretion or tectonic erosion, and this in turn must be controlled by rates of continental erosion. What controls continental erosion is still debated, yet it is clear that tectonically driven rock uplift and climate are key processes (Burbank et al. 2003; Dadson et al. 2003; Zhang et al. 2001). Thus orogeny, uplifting blocks of crust above sea level, increases erosion and feeds sediment to the continental margins where some of it can be recycled into the mantle.

The topography of Earth is dominated by deep oceanic basins that contrast with continents that mostly lie close to sea level, except in regions of recent tectonic deformation (Fig. 16). An analysis of global topography shows that most ocean basins lie 3-7 km below sea level, while the vast majority of continental crust lies $<500 \mathrm{~m}$ above sea level (Fig. 17). Sedimentary records indicate that the volume of water on the planet's surface has approximately filled the oceanic basins since Precambrian times, neither underfilling nor overspilling by more than $\sim 200 \mathrm{~m}$ (Haq et al. 1987). This state has lasted likely since the Archaean (Campbell \& Taylor 1983; Harrison 1994; McLennan \& Taylor 1982; Nisbet 1987). The volume of those basins is determined by the volume, density and thickness of equilibrium continental crust relative to the oceanic crust, but what controls crustal thickness? Clift \& Vannucchi (2004) calculated that at modern rates of plate motion arc 
597 or continental) because melt production would be incapable of keeping up with mass removal

598 rates. In addition, delamination of dense lower crustal gabbronorite and pyroxenite in active 599 arcs limits the thickness that can formed by magmatism. Behn \& Kelemen (2006)

600 demonstrated that such lithologies are convectively unstable relative to the underlying 601 mantle. Seismic velocity data show that most lower crust in modern arcs has seismic 602 velocities $(\mathrm{Vp})$ of more than $7.4 \mathrm{~km} / \mathrm{s}$, compared to the $\mathrm{Vp}>7.4 \mathrm{~km} / \mathrm{s}$ of the dense 603 gabbronorite. This observation suggests that gravitationally unstable material must founder 604 rapidly on geologic timescales. As a result greater crustal thicknesses would thus require 605 additional tectonically driven horizontal compression.

606 Although trench processes act as an initial limit on crustal thicknesses the narrow 607 range of 36-41 km found in most continental crust (Christensen \& Mooney 1995) must in 608 part reflect the erosion of subaerially exposed crust. Except in regions of long-term extreme 609 aridity (e.g., Atacama Desert)(Hartley et al. 2005) orographic rain at mountain fronts will 610 necessarily drive erosion and move crustal material from areas of thickened crust on to 611 continental margins in the form of sediment. Even where climate inhibits erosion the process 612 of continental drift will tend to move crustal blocks out of arid regions and into wetter ones 613 over time periods of $10^{7}-10^{8}$ yrs, so that eventually tectonically or magmatically thickened 614 crust must be eroded and freeboard reduced to sea level. The "excess" continental crust (i.e., 615 eroded sediment) is returned to the mantle by subduction, either directly to a trench or to a 616 passive margin that is eventually involved in collision with a trench.

617 No long-term trend in global sea level has been recorded over $10^{7}-10^{9}$ yrs (Hallam 618 1992; Haq et al. 1987) and there appears to be good evidence for ocean depths in the 619 Archaean being close to modern values (Harrison 1999; Nisbet 1987; Wise 1974). However, 620 there seems no a priori reason why the volume of water should not cause sea level to 
621 overspill the oceanic basins and flood the continents to a depth of $1 \mathrm{~km}$ or more. Conversely,

622 if the volume of water were much less, or the oceanic basins much larger, then sea level 623 would lie well below the level of the continents (Fig. 17). Nonetheless, evidence from the

624 stratigraphic record shows that this has not happened. Harrison (1999) argued that continental 625 freeboard above sea level is controlled by the volume of the water at Earth's surface, which 626 varies over long periods of time $\left(10^{7}-10^{9} \mathrm{yrs}\right)$. Erosion of elevated topography due to 627 precipitation and glaciation will tend to reduce elevated terrain to sea level (Harrison 1994), 628 thinning the crust as it does so. Conversely, thin, submarine arc crust will tend to be built up 629 to sea level by the compressive tectonic forces favoured by sediment-starved trenches and 630 where coupling between subducting and over-riding plates is stronger (Wells et al. 2003), as 631 well as by magmatic accretion. The process is self-limiting because a thickening, uplifting 632 margin will tend to result faster erosion, more sediment in the trench and a reduction in 633 tectonic coupling. Thus continental crustal thickness reflects the combined influence of 634 seawater volume and the ability to subduct significant volumes of crust at both accretionary 635 and erosive margins.

\section{Erosion of Orogenic Topography}

638 The rate at which continental crust is recycled through subduction zones is dependent 639 on how fast orogenic topography can be reduced to sea level. Mountain belts are prone to 640 reactivation after their initial peneplanation, yet they rarely regain major altitude after this 641 initial phase of crustal thinning. The Urals reach heights $>1800 \mathrm{~m}$ more than 250 m.y. after 642 their formation (Brown et al. 2006), yet generally Mesozoic and especially Palaeozoic belts 643 rarely exceed $1 \mathrm{~km}$ elevations. The highest mountains on Earth represent Cenozoic and 644 modern plate collisions. Arc-continent collisional orogens reduce to sea level as a result of 
645 gravitational collapse into the new trench immediately after the collision point has passed 646 (Clift et al. 2003b; Teng 1996), but continent-continent collisions are often different and 647 require extended periods of erosion before equilibrium is attained, i.e. before they are 648 reduced in altitude close to sea level. For example, the mountains formed by the Acadian 649 Orogeny after closure of the Iapetus Ocean reached peak metamorphism around $395 \mathrm{Ma}$ 650 (Armstrong et al. 1992) but are truncated by a peneplain erosion unconformity of Late 651 Carboniferous age $(\sim 320 \mathrm{Ma})$ in western Ireland (Graham 1981), suggesting $\sim 75 \mathrm{Ma}$ to remove the excess crust by erosion.

654 of a very large, long-lived orogen. The volume of eroded rock in the basins around Tibet can 655 be used to determine long-term erosion rates. Eroded rock volumes, with a correction for 656 sediment porosity, are shown in Table 5. These values are determined from regional seismic 657 profiles and are largely from the existing studies of Métivier et al. (1999) and Clift et al. 658 (2004). As well as the sediments now seen in the major depocentres we estimate those sediments already lost by subduction, especially in the Andaman Arc, where sediment has 660 been subducted at a rate of $1.3 \times 10^{5} \mathrm{~km}^{3} / \mathrm{m} . \mathrm{y}$. in the recent geologic past, although this would 661 have been less earlier since the fan has grown significantly in the Neogene (Métivier et al. 662 1999). We estimate that $\sim 3.2 \times 10^{6} \mathrm{~km}^{3}$ has been subducted in this way since $50 \mathrm{Ma}$, 663 assuming no Bengal Fan at that time, and progressive subsequent growth. Subducted losses in 664 the Indus Fan via subduction in the Makran Accretionary Complex would be somewhat less, 665 because that fan has been cut off from the Gulf of Oman since 20 Ma by uplift of Murray 666 Ridge (Mountain \& Prell 1990), so that only the Palaeogene erosional record is being lost. 667 The basins of continental Central Asia, including the Tarim, Junngar and Hexi Corridor 668 Basins account for $1.9 \times 10^{6} \mathrm{~km}^{3}$ (Métivier et al. 1999). The excess crustal mass in Tibet is 
669 estimated using a figure of $3.5 \times 10^{6} \mathrm{~km}^{2}$ as the area of the plateau, and the figure of $70 \mathrm{~km}$

670 for the crustal thickness, around double the standard equilibrium continental crust.

671 The average long-term rate of erosion is $0.56 \mathrm{AU}$ since $50 \mathrm{Ma}$; requiring $220 \mathrm{~m} . \mathrm{y}$. to

672 reduce Tibet crust from 70 to $35 \mathrm{~km}$ thickness, if the plateau ceased growing today and that

673 long-term rate of erosion was maintained (Fig. 18). Whether this is a reasonable figure is

674 debatable because mass accumulation rates in East Asian marginal seas appear to have

675 increased rapidly after $33 \mathrm{Ma}$ (Clift et al. 2004), while recent palaeo-weathering studies from

676 South and East Asia suggest an initial intensification of monsoon summer rains after $22 \mathrm{Ma}$

677 (Clift \& Plumb 2008). As rains are a major trigger for continental erosion much of the

678 sediment now seen around Asia has been eroded since that time. Using 33 and $22 \mathrm{Ma}$ as the

679 start dates for the bulk of the erosion yields average erosion rates of 0.9 and 1.3 AU

680 respectively, and consequently durations of 145 and 97 m.y. to reduce Tibet back to sea level.

681 Thus it appears that little orogenic topography can survive at the Earth's surface beyond 200

682 Ma, without the excess crust being recycled to the mantle via subduction zones.

683

684 Summary

685 Geochemical arguments strongly suggest that much of the modern continental crust 686 has been formed in or at least recycled via subduction zones. Subduction zones are also the 687 locations where crustal material is returned to the upper mantle both via tectonic erosion of 688 forearc crust and subduction of sediment in erosive margins, or via the inefficient process of 689 subduction accretion that allows $\sim 83 \%$ of the incoming sedimentary column to be subducted 690 over long periods of geologic time (Clift \& Vannucchi 2004). Total continental mass 691 subduction rates are approximately 3.0 Armstrong Units $\left(1 \mathrm{AU}=1 \mathrm{~km}^{3} / \mathrm{yr}\right)$, of which 1.65 692 AU comprises subducted sediments and 1.33 AU tectonically eroded forearc crust (Fig. 18). 
693 Recycling of crust by subduction of passive margins in continent-continent and arc-passive

694 margin collisions is substantially less, averaging 0.4 AU during the Cenozoic.

The process of subduction erosion is still not well understood and may involve both

696 mechanical abrasion of the forearc wedge and/or fluid induced fracturing of the forearc

697 (Vannucchi et al. 2008; von Huene et al. 2004). What is clear is that erosion can operate in 698 several fashions. Individual margins may retreat landwards in a wholesale, steady-state mode, 699 such as apparently is the case in the South Sandwich, Tonga and Marianas Arcs. 700 Alternatively, trench retreat may occur by erosion of the trenchward forearc coupled with 701 landward underplating, such as seen in the central and northern Andean margin, both associated with trench sediment thicknesses of $<1 \mathrm{~km}$. Tectonic erosion is likely a discontinuous process, as suggested by tephra records from offshore Costa Rica (Clift et al. 2005a), a region generally associated with long-term tectonic erosion (Vannucchi et al. 2001). Geochemical data indicate that subduction erosion in the Central American arc is achieved via periods of slow tectonic erosion interrupted by shorter periods of accelerated erosion, likely driven by seamount subduction, and by periods of sediment accretion.

Subducted crustal losses must be balanced by new production via arc magmatism. Average global melt production rates are 96 and $64 \mathrm{~km} 3 / \mathrm{m} . \mathrm{y} . / \mathrm{km}$ in oceanic and continental

710 arc respectively, close to those estimated by seismic methods, after correction for subduction 711 erosion losses (Holbrook et al. 1999; Suyehiro et al. 1996). The accretion of oceanic arc crust 712 to continental passive margins during arc-continent collision is crucial to maintaining the 713 volume of the continental crust without excessive melt production in continental arcs. Mass

714 balancing across the Taiwan collision zone suggests that almost $90 \%$ of the colliding Luzon

715 Arc crust is accreted to the margin of Asia in that region. The accretion is seen as a steady716 state migrating processes, with the collapsed arc and deformed passive margin of China 
717 underlying the new Ryukyu forearc ridge and Okinawa Trough. Rates of exhumation and

718 sediment recycling indicate that the subaerial phase of orogenesis spans only $\sim 4$ m.y.,

719 although initial collision with the deep-water passive margin must have predated that time by $720 \quad 2-3$ m.y.

721 Subduction of sediment in both erosive and inefficient accretionary margins provides

722 a mechanism for returning continental crust to the upper mantle and appears to be

723 fundamental in governing the thickness of the continental crust. Sea level controls rates of

724 continental erosion, reducing topography caused by tectonically over-thickened crust to sea

725 level over timescales of 100-200 Ma. Much of this eroded sediment is delivered directly or

726 indirectly to trenches, allowing its return to the upper mantle. Thus sea level and the volume

727 of water on the Earth's surface controls crustal thicknesses over periods of $10^{7}-10^{9} \mathrm{yrs}$.

728

729 Acknowledgements

730 PC wishes to thank the Alexander von Humboldt Foundation for support during the writing

731 of this paper at the University of Bremen, as well as the College of Physical Sciences,

732 University of Aberdeen for its generous support. PRIN 2005 Subduction complex dynamics:

733 mass transfer in fossil systems and comparisons with modern examples, funded PV. We

734 thank Dennis Brown and David Tappin for their constructive comments in review for 735 improving the manuscript.

736 


\section{Figure Captions}

737

738 Figure 1. Schematic map of the global subduction system showing the distribution of accreting versus eroding subduction zones. Accretionary margins are shown with filled barbs on the plate boundary, while empty barbs mark erosive margins. Modified after Clift \& Vannucchi (2004), reproduced with permission of the American Geophysical Union.

Figure 2. Schematic cartoons showing the features common to the two basic types of active margin from Clift \& Vannucchi (2004). (A) Accretionary margins, such as Cascadia, are characterized by forearc regions comprised thrusted and penetratively deformed trench and oceanic sediments that often develop mud diapirism and volcanism due to sediment overpressuring. Gas hydrate zones are also commonly associated with structures in the wedge, (B) in contrast erosive plate margins, such as Tonga, are marked by steep trench slopes, comprised of volcanic, plutonic and mantle rocks. Sedimentary rocks are typically limited to the forearc basin, where they may be faulted but are not strongly sheared in the fashion of an accretionary wedge. In the Marianas serpentinite mud volcanism is recorded. Reprinted with permission from the American Geophysical Union.

754 Figure 3. Diagrams showing the relationship of (A) orthogonal convergence rates and (B) trench sediment thicknesses to the net crustal growth or loss along the global active margins, from Clift \& Vannucchi (2004). Modified with permission from American Geophysical Union. Large circles show erosive plate margins for which a trench retreat is well defined, compared to the small circles representing margins for which tectonic erosion rates are inferred. $\mathrm{ALE}=$ Aleutians; $\mathrm{AND}=$ Andaman; $\mathrm{BC}=$ British Columbia; $\mathrm{COS}=$ Costa Rica; 
$760 \mathrm{ECU}=$ Ecuador; GUA $=$ Guatemala; JAV $=$ Java; KER $=$ Kermadec $;$ KUR $=$ Kurile; LA =

761 Lesser Antilles; LUZ = Luzon-Philippine; MAK = Makran; MED = Mediterranean; MEX = 762 Mexico $;$ MIN $=$ Mindanao $;$ NAN $=$ Nankai $;$ NC $=$ Northern Chile $;$ NIC $=$ Nicaragua $;$ PER $=$

763 Peru; RYU = Ryukyu; SC = Southern Chile; SOL = Solomons; SS = South Sandwich; SUM

$764=$ Sumatra; TAI $=$ Taiwan; TON $=$ Tonga; WAS $=$ Washington-Oregon.

765

766

Figure 4. (A) Multichannel seismic reflection profile HIG-14, with (B) close-up of Lima

Basin, and (C) after depth conversion and interpretation of age structure, largely correlated from ODP Site 679 located at the landward end of the profile.

769

770

Figure 5. Bathymetric map of the eastern Pacific offshore Peru and Chile showing the locations of the basins discussed in the text, as well as the major bathymetric ridges now in collision with the Andean margin. Depth data are from GEBCO. Depth contours in $500 \mathrm{~m}$ intervals. Boxes show regions of detailed offshore geophysical (seismic and bathymetric mapping) surveys. Re-printed with permission from Geological Society of America (Clift \& Hartley 2007).

Figure 6. Reconstructed depth to basement for a series of Andean forearc sedimentary basins during the Cenozoic showing the general slow rate of subsidence consistent with long-term net mass loss during subduction erosion. Lima Basin (ODP Site 679 on the inner shelf, and ODP Site 682 on the trench slope) reconstruction is from Clift et al. (2003). Pisco Basin data are taken from Dunbar et al. (1990) and Tsuchi (1992). Mejillones Peninsula data are from Hartley \& Jolley (1995), Krebs et al. (1992), Ortlieb et al. (1996) and Ibaraki (2001). Caldera 
784 (2005) respectively. Height of black vertical bars shows the magnitude of the uncertainties in

785 palaeo-water depth. Altered from Clift \& Hartley (2007) and with permission from 786 Geological Society of America.

787

788 Figure 7. Cartoon showing the alternative modes of subduction erosion. (A) shows the slower 789 and non-steady state style of erosion as typified by Neogene northern and central Andes in 790 which erosion is concentrated close to the trench, while the coast remains approximately 791 stationary. Trench retreat is accommodated by steepening of the forearc taper (B) shows the 792 fast, steady-state mode of erosion, apparently operating in the western Pacific, where taper angle remains constant and trench retreat rate corresponds to loss of complete crustal 794 thickness.

Figure 8. (A) Plot of $\varepsilon_{\mathrm{Nd}}$ and $\delta^{7} \mathrm{Li}$ shows that while the majority of tephra glasses at ODP Sites 1039, 1041 and 1043 could be explain by a petrogenesis mixing recycled MORB crust and subducted sediments, an additional, likely forearc component is required. Sediment data from Chan and Kastner (2000) and Kelly (2003). (B) Diagrams showing the evolving Li and $\mathrm{Nd}$ isotopic composition of Costa Rican tephras since 2.5 Ma. Histogram of $\varepsilon_{\mathrm{Nd}}$ values for modern Costa Rica is from GEOROC. Modern $\delta^{7} \mathrm{Li}$ value for Arenal volcano from Chan et al. (1999) , Nd data from Feigenson et al. (2004). Sediment proportion of petrogenesis is

803 calculated from end member mixing model based on $\mathrm{Nd}$ isotopes. Diagram shows the strong 804 temporal variability in the degree of sediment and forearc crustal recycling, likely linked to 805 seamount collision. 
807 Figure 9. Bathymetric map of the Taiwan region showing the collisional orogen, the opposing

808 subduction polarities and the Okinawa Trough opening in the wake of orogenic collapse. The 809 numbered lines adjacent to the plate boundary show the inferred time of peak arc collision

810 between the Luzon Arc and the passive margin of China in the past and future. Map is

811 labelled to show the different stage of arc-continent collision along strike. Dashed line shows

812 location of the Taiwan-Sinzi Foldbelt, interpreted as remnants of the former collisional

813 orogen, while the grey line shows the location of the modern arc volcanic front, focused by

814 extension in the Okinawa Trough close to Taiwan (re-printed from Clift et al. 2003).

815

816 Figure 10. Cartoon showing the proposed tectonic model for Luzon Arc collision in Taiwan.

817 Arc crust (cross pattern) acts much like a snow plough, deforming and uplifting sediments of

818 the Chinese passive margin (dotted pattern). As the collision point migrates along the margin

819 the compressive stress is released and the orogen collapses to form a basin, subsequently

820 infilled by sediment, largely eroded from the orogen (horizontal shading).

821

822 Figure 11. Cross sections through the Taiwan collision zone, south of the collision zone, at

823 the collisional maximum in central Taiwan and across the Okinawa Trough and Ryukyu

824 forearc, interpreted to be in a post-collisional state. Crustal structure under Taiwan is inferred

825 from the seismic evidence of Carena et al. (2002) shown as black and grey dots projected on

826 to the section from a number of major faults in the central Taiwan region. See Figure 9 for

827 locations of the sections.

828

829 Figure 12. Diagram showing the relative volumes of accreted and subducted arc crust, versus

830 eroded sediment in the Taiwan collision zone. The figure shows the relatively high efficiency 
831 of the accretion process in transferring oceanic arc crust to the Asian margin (88\%). Crustal

832 volumes are derived from the balanced cross sections shown in Figure 11.

833

834 Figure 13. (A) Simplified geological map of Taiwan showing the map tectonic units that 835 comprise the island and the location of the Ilan Basin along the strike of the Lishan Fault,

836 which separates the Hsüehshan and Backbone Ranges. (B) Diagram showing the rates of

837 erosion along the Central Ranges of Taiwan, running south to north. Rates are based on

838 fission track analysis of Willett et al.(2003). Modelled depths of erosion infer a start of

839 collision at 5, 3 and $2 \mathrm{Ma}$ at the northern end of Taiwan and a propagating collisional orogen

840 younging to the south.

841

842 Figure 14. Diagram showing the balance between the sediments and sedimentary rocks

843 available to form the Taiwan Orogen within the Luzon forearc and Chinese passive margin

844 and the measured volume of the Taiwan thrust sheets and eroded volumes predicted for

845 collision starting at different times for that point on the Luzon Arc now directly under the

846 northern tip of Taiwan. The generally accepted 5 Ma collision age appears to require more

847 material than is actually available in the system.

849 Figure 15. Diagram redrawn from Willett et al. (1993) showing that crust from the

850 subducting plate (China) is fluxed through the orogen, so that erosion at the mountain front

851 can continue indefinitely without exposing any deeper level material at any given point. This

852 type of horizontal transport must be occurring if the $20 \mathrm{~km}$ of erosion has occurred in the

853 Central Ranges without higher grade metamorphic rocks being exposed. 
855 Figure 16. Hypsometry of the Earth, showing the bipolar distribution between ocean basins

856 and continental crust that shows a particular sharp maximum close to sea level, representing 857 the equilibrium state of the continental crust and equivalent to a thick of $\sim 36 \mathrm{~km}$ with normal 858 density structure (Rudnick \& Fountain 1995).

859

860 Figure 17. Cartoon showing the two states of continental crust at subduction margins. Thin

861 crust lying below sea-level is not eroded and is built up by voluminous melt production,

862 while subaerial continental arcs have low melt production and are continuously eroded to sea-

863 level, even when active.

864

865 Figure 18. Diagram showing the comparative rates of sediment recycling in subduction zones

866 relative to tectonic erosion, arc magmatism, ocean island basalt (OIB) magmatism,

867 subduction accretion and the erosional flux from Asia.

868

869 Table 1. Summary of the lengths of Cenozoic mountain belts along which passive margins

870 have been subducted since $65 \mathrm{Ma}$, together with an estimate of the subducted crustal volumes

871 assuming $50 \%$ of the margins are volcanic and $50 \%$ non-volcanic.

872

873 Table 2. Summary of some of the major tectonic characteristics of the world's subduction

874 zones, shown in Figure 1. Values are modified after those presented by Clift \& Vannucchi

875 (2004), especially with regard to the North Chile and Peruvian margins. Magmatic

876 production rates are set to balance subducted losses and are scaled to reflect convergence

877 velocity.

878 
879 Table 3. Rates of mass recycling for major crustal mass repositories. AU = Armstrong Unit

$880\left(1 \mathrm{~km}^{3} / \mathrm{yr}\right.$.). Arc magmatic production rate is calculated to match the degree of crustal

881 subduction (sediment and forearc crust). Subduction accretion rate is from Clift \& Vannucchi

882 (2004). Mid Ocean Ridge Basalt (MORB) production rate is from Dick et al. (2003). Ocean

883 Island Basalt (OIB) production is from S. Hart (pers. comm., 2006). Total river discharge is

884 from Milliman (1997). Asian Cenozoic erosion rate is from Clift et al. (2004).

885

886 Table 4. Estimates of the volumes of crustal material found in the colliding Luzon Arc, the

887 Taiwan Orogen and in the post-collisional Ryukyu-Okinawa Arc system, together with total

888 erosion estimates for the Taiwan Orogen estimated assuming different ages for the start of

889 collision at 5, 3 and 2 Ma.

890

891 Table 5. Volumes of basins in Asia that have largely been filled by erosion of the Himalaya 892 and Tibetan Plateau (data compiled from Clift et al. (2004) for the marine and foreland basin 893 and from Métivier et al. (1999) for the basins of Central Asia). This volume of sediment can

894 be used to calculate long-term average rates of sediment production. Given the modern size 895 of Tibet and the known "excess" crustal thickness above average continental values the time 896 needed to remove Tibet can be estimated. Erosion has been much faster since $\sim 33 \mathrm{Ma}$ and 897 thus a range of possible values can be calculated assume erosion starting after collision $\sim 50$ 898 Ma or just since 33 Ma.

899

900 Table 6. Estimates average rates of erosion for the Himalaya and Tibetan Plateau assuming 901 uplift and erosion started at $50 \mathrm{Ma}$, close to time of collision, and alternatively at $33 \mathrm{Ma}$ when 902 erosion rates are seen to greatly accelerate in Asia (Clift et al. 2004). 
903

904 
905

906

Aitchison, J. C., Badengzhu, D., Davis, A. M., Liu, J., Luo, H., Malpas, J., McDermid, 907 I. M. C., Wu, H., Ziabrev, S. \& Zhou, M. F. 2000. Remnants of a Cretaceous intra908 oceanic subduction system within the Yarlung-Zangbo suture (southern Tibet). Earth and Planetary Science Letters, 183, 231- 244.

910

Albarede, F. \& BrouXel, M. 1987. The Sm/Nd secular variation of the continental crust and the depleted mantle. Earth and Planetary Science Letters, 82, 25-35.

912

Armstrong, R. L. \& HARMOn, R. S. 1981. Radiogenic Isotopes: The case for crustal recycling on a near-steady-state no-continental-growth Earth. Philosophical Transactions of the Royal Society of London. Series A, Mathematical and Physical Sciences, 301(1461), 443-472.

916

Armstrong, T. R., Tracy, R. J. \& Hames, W. E. 1992. Contrasting styles of Taconian, Eastern Acadian and Western Acadian metamorphism, central and western New England. Journal of Metamorphic Geology, 10, 415-426.

Atherton, M. P. \& Petford, N. 1996. Plutonism and the growth of Andean crust at 9 degrees S from 100 to 3 Ma. Journal of South American Earth Sciences, 9, 1-9.

921

Bangs, N. L. B., Gulick, S. P. S. \& ShIPley, T. H. 2006. Seamount subduction erosion in the Nankai Trough and its potential impact on the seismogenic zone. Geology, 34, 701704, doi: 10.1130/G22451.1.

Barth, M. G., McDonough, W. F. \& Rudnick, R. L. 2000. Tracking the budget of $\mathrm{Nb}$ and Ta in the continental crust. Chemical Geology, 165, 197-213.

927

Behn, M. \& Kelemen, P. 2006. Stability of arc lower crust; insights from the Talkeetna Arc section, south central Alaska, and the seismic structure of modern arcs. Journal of Geophysical Research, 111(B11), doi:10.1029/2006JB004327.

Bloomer, S. H. \& Hawkins, J. W. 1987. Petrology and geochemistry of boninite series volcanic rocks from the Mariana trench. Contributions to Mineralogy and Petrology, 97, $361-377$.

Boher, M., Abouchami, W., Michard, A., Albarede, F. \& Arndt, N. T. 1992. Crustal growth in West Africa at 2.1 Ga. Journal of Geophysical Research, 97, 345-36.

Bowring, S. A. \& Housh, T. 1995. The Earth's early evolution. Science, 269, 1535-1540. 
935 Brown, D., Puchkov, V., Alvarez-Marron, J., Bea, F. \& Perez-Estaun, A. 2006.

936 Tectonic processes in the Southern and Middle Urals; an overview. In European 937 lithosphere dynamics. (Eds, D. G. GEE and R. A. STEPHENSON), London: Geological 938 Society, Memoirs, 32, pp. 407-419.

939 Burbank, D. W., Blythe, A. E., Putkonen, J., Pratt-Sitaula, B., Gabet, E., Oskins, 940 M., Barros, A. \& OJHA, T. P. 2003. Decoupling of erosion and precipitation in the 941 Himalayas. Nature, 426, 652-655.

942 Busby, C., Fackler Adams, B., Mattinson, J. \& Deoreo, S. 2006. View of an intact 943 oceanic arc, from surficial to mesozonal levels: Cretaceous Alisitos arc, Baja California. Journal of Volcanology and Geothermal Research, 149, 1- 46.

945 CAMPBell, I. H. \& TAYloR, S. R. 1983. No water, no granites; no oceans, no continents. 946 Geophysical Research Letters, 10(11), 1061-1064.

947 Carena, S., Suppe, J. \& KaO, H. 2002. Active detachment of Taiwan illuminated by small 948 earthquakes and its control of first-order topography. Geology, 30, 935-938.

949 Carr, M. J., Feigenson, M. D., Patino, L. C. \& Walker, J. A. 2003. Volcanism and 950 geochemistry in Central America: Progress and problems, in Inside the Subduction 951 952 Factory. (Ed, J. EILER), Washington, D.C: American Geophysical Union, Geophysical Monograph, 138, pp. 153-174.

CASEY, J. F. \& Dewey, J. F. 1984. Initiation of subduction zones along transform and accreting plate boundaries, triple-junction evolution, and forearc spreading centresimplications for ophiolitic geology and obduction. In Ophiolites and Oceanic Lithosphere. (Eds, I. G. GASs, S. J. LiPPARD and A. W. SheltON), London: Geological Society, Special Publication, 13, pp. 269-290.

Chan, L.-H., Leeman, W. P. \& You, C. F. 1999. Lithium isotopic composition of Central American Volcanic Arc lavas: Implications for modification of subarc mantle by slabderived fluids. Chemical Geology, 160, 255-280.

Chan, L.-H. \& KASTNER, M. 2000. Lithium isotopic compositions of pore fluids and sediments in the Costa Rica subduction zone; implications for fluid processes and sediment contribution to the arc volcanoes. Earth and Planetary Science Letters, 183, 275-290. 
Chemenda, A. I., Yang, R. K., Hsieh, C. H. \& Groholsky, A. L. 1997. Evolutionary model for the Taiwan collision based on physical modeling. Tectonophysics, 274, 253274.

Chen, P.-F., Huang, B.-S. \& Liang, W.-T. 2004. Evidence of a slab of subducted lithosphere beneath central Taiwan from seismic waveforms and travel times. Earth and Planetary Science Letters, 229, 61-71.

Chi, W. R., NAMSON, J. \& SuPPE, J. 1981. Stratigraphic record of plate interactions in the Coastal Range of eastern Taiwan. Geological Society of China Memoir, 4, 155-194.

Christensen, N. I. \& MoOney, W. D. 1995. Seismic velocity structure and composition of the continental crust; a global view. Journal of Geophysical Research, 100, 9761-9788.

Clift, P. \& VAnNuCChi, P. 2004. Controls on tectonic accretion versus erosion in subduction zones; implications for the origin and recycling of the continental crust. Reviews of Geophysics, 42, no.2, 31.

Clift, P. D. \& MacLeOd, C. J. 1999. Slow rates of subduction erosion estimated from subsidence and tilting of the Tonga forearc. Geology, 27(5), 411-414.

Clift, P. D., Pecher, I., Kukowski, N. \& Hampel, A. 2003a. Tectonic erosion of the Peruvian forearc, Lima Basin, by subduction and Nazca Ridge collision. Tectonics, 22, 1023, doi:10.1029/2002TC001386.

Clift, P. D., Schouten, H. \& Draut, A. E. 2003b. A general model of arc-continent collision and subduction polarity reversal from Taiwan and the Irish Caledonides. In IntraOceanic Subduction Systems; Tectonic and Magmatic Processes. (Eds, R. D. LARTER and P. T. LEAT), London: Geological Society, Special Publication, 219, pp. 81-98.

Clift, P. D., Schouten, H. \& Draut, A. E. 2003c. A general model of arc-continent 992 collision and subduction polarity reversal from Taiwan and the Irish Caledonides. In IntraOceanic Subduction Systems; Tectonic and Magmatic Processes. (Eds, R. D. LARTER and P. T. LEAT), London: Geological Society, special publication, 219, pp. 81-98.

Clift, P. D., Layne, G. D. \& Blusztajn, J. 2004. Marine sedimentary evidence for monsoon strengthening, Tibetan uplift and drainage evolution in east Asia. In ContinentOcean Interactions in the East Asian Marginal Seas. (Eds, P. CLIFT, W. Kunnt, P. WANG and D. HAYES), Washington, DC: American Geophysical Union, Geophysical Monograph, 149, pp. 255-282. 
996 Clift, P. D., Chan, L.-H., Blusztajn, J., Layne, G. D., Kastner, M. \& Kelly, R. K. 997 2005a. Pulsed subduction accretion and tectonic erosion reconstructed since 2.5 Ma from 998 the tephra record offshore Costa Rica. Geochemistry, Geophysics, Geosystems, 999 6(Q09016), doi:10.1029/2005GC000963.

1000 Clift, P. D., Pavlis, T., DeBari, S. M., Draut, A. E., Rioux, M. \& Kelemen, P. B. 2005 b. 1001 Subduction erosion of the Jurassic Talkeetna-Bonanza Arc and the Mesozoic accretionary 1002 tectonics of western North America. Geology, 33(11), 881-884.

1003 Clift, P. D. \& Hartley, A. 2007. Slow rates of subduction erosion along the Andean 1004 margin and reduced global crustal recycling. Geology, 35, 503-506.

1005 Clift, P. D. \& Plumb, R. A. 2008. The Asian Monsoon: Causes, History and Effects. 1006 Cambridge: Cambridge University Press, in press.

1007 Crespi, J., ChAN, Y. C. \& SwAIM, M. 1996. Synorogenic extension and exhumation of the 1008 Taiwan hinterland. Geology, 24, 247-250.

1009 Dadson, S., Hovius, N., Chen, H., Dade, W. B., Hsieh, M. L., Willett, S., Hu, J. C., 1010 Horng, M. J., Chen, M. C., Stark, C. P., Lague, D. \& Lin, J. C. 2003. Links between 1011 erosion, runoff variability and seismicity in the Taiwan orogen. Nature, 426, 648-651.

1012 DeBari, S. M. \& Coleman, R. G. 1989. Examination of the deep levels of an island arc: 1013 evidence from the Tonsina Ultramafic-Mafic assemblage, Tonsina, Alaska. Journal of 1014 Geophysical Research, 94, 4373-4391.

1015 Dewey, J. F. \& Windley, B. F. 1981. Growth and differentiation of the continental crust. 1016 Philosophical Transactions of the Royal Society, London A, 301, 189-206.

1017 Dick, H. J. B., Lin, J. \& Schouten, H. 2003. An ultraslow-spreading class of ocean ridge. $1018 \quad$ Nature, 426, 405-412.

1019 Draut, A. E., Clift, P. D., Hannigan, R. E., Layne, G. \& Shimizu, N. 2002. A model for 1020 continental crust genesis by arc accretion; rare earth element evidence from the Irish 1021 Caledonides. Earth and Planetary Science Letters, 203(3-4), 861-877.

1022 Dunbar, R. B., Marty, R. C. \& BAKer, P. A. 1990. Cenozoic marine sedimentation in the 1023 Sechura and Pisco basins, Peru. Palaeogeography Palaeoclimatology Palaeoecology, 77, $1024 \quad 235-261$.

1025 Ellam, R. M. \& Hawkesworth, C. J. 1988. Is average continental crust generated at 1026 subduction zones? Geology, 16, 314-317. 
1027 ElliotT, T., Zindler, A. \& Bourdon, B. 1999. Exploring the kappa conundrum; the role of 1028 recycling in the lead isotope evolution of the mantle. Earth and Planetary Science Letters, 169, 129-145.

Feigenson, M. D., Carr, M. J., Maharaj, S. V., Juliano, S. \& Bolge, L. L. 2004. Lead isotope composition of Central American volcanoes: Influence of the Galapagos plume. Geochemistry Geophysics Geosystems, 5(Q06001), doi:10.1029/ 2003GC000621. .

Fuller, C. W., Willett, S. D., Hovius, N. \& Slingerland, R. 2003. Erosion rates for Taiwan mountain basins: new determinations from suspended sediment records and a stochasticmodel of their variation. Journal of Geology, 111, 71-87.

Fuller, C. W., Willett, S. D., Fisher, D. \& LU, C. Y. 2006. A thermomechanical wedge model of Taiwan constrained by fission-track thermochronometry. Tectonophysics, 425(14), 1-24.

GaO, S., Rudnick, R. L. \& YuAn, H.-L. 2004. Recycling lower continental crust in the North China craton. Nature, 432, 892-897.

Goldstein, S. L., ARndt, N. T. \& Stallard, R. F. 1997. The history of a continent from U$\mathrm{Pb}$ ages of zircons from Orinoco River sand and $\mathrm{Sm}-\mathrm{Nd}$ isotopes in Orinoco Basin river sediments. Chemical Geology, 139, 271-286.

GRAHAM, J. R. 1981. Fluvial sedimentation in the Lower Carboniferous of Clew Bay, County Mayo, Ireland. Sedimentary Geology, 30(3), 195-211.

Hallam, A. 1992. Phanerozoic sea-level changes. New York, NY: Columbia University Press, p. 266,

HAMPEL, A. 2002. The migration history of the Nazca Ridge along the Peruvian active margin: a re-evaluation. Earth and Planetary Science Letters, 203(2), 665-679.

HaQ, B. U., Hardenbol, J. \& Vail, P. R. 1987. Chronology of fluctuating sea levels since the Triassic. Science, 235, 1156-1167.

HARRISON, C. G. A. 1994. Rates of continental erosion and mountain building. Geologische Rundschau, 83, 431-437.

HARrison, C. G. A. 1999. Constraints on ocean volume change since the Archean. Geophysical Research Letters, 26, 1913-1916.

Hartley, A. J. \& Jolley, E. J. 1995. Tectonic implications of Late Cenozoic sedimentation from the Coastal Cordillera of northern Chile $\left(22-24^{\circ} \mathrm{S}\right)$. Journal of the Geological Society, 152, 51- 63 . 
Hartley, A. J., Chong, G., Houston, J. \& Mather, A. E. 2005. 150 million years of climatic stability; evidence from the Atacama Desert, northern Chile. Journal of the Geological Society, 162, 421-424.

1062

HAwkesworth, C. J. \& KeMP, A. I. S. 2006. Evolution of the continental crust. Nature, 443, 811-817, doi:10.1038/nature05191.

1064

Hayes, D. E. \& Lewis, S. D. 1984. A geophysical study of the Manila Trench, Luzon, Philippines; 1, Crustal structure, gravity, and regional tectonic evolution. Journal of Geophysical Research, 89, 9171-9195.

HILDE, T. W. C. 1983. Sediment subduction versus accretion around the Pacific. Tectonophysics, 99, 381-397.

Hildebrand, R. S. \& Bowring, S. A. 1999. Crustal recycling by slab failure. Geology, 27, $11-14$.

Holbrook, W. S., Lizarralde, D., McGeary, S., N., B. \& J., D. 1999. Structure and composition of the Aleutian island arc and implications for continental crustal growth. Geology, 27, 31-34.

Huang, C. Y., Yuan, P. B., Lin, C. W. \& Wang, T. K. 2000. Geodynamic processes of Taiwan arc-continent collision and comparison with analogs in Timor, Papua New Guinea, Urals and Corsica. Tectonophysics, , 325, 1-21, doi: 10.1016/S00401951(00)00128-1.

HuAnG, C. Y., YuAn, P. B. \& TSAO, S. H. 2006. Temporal and spatial records of active arccontinent collision in Taiwan: A synthesis. Geological Society of America Bulletin, 118, 274-288.

IBARAKI, M. 2001. Neogene planktonic foraminifera of the Caleta Herradura de Mejillones section in northern Chile: Biostratigraphy and paleoceanogoraphic implications. Micropalaeontology, 47, 257-267.

JACOBSEN, S. B. 1988. Isotopic constraints on crustal growth and recycling. Earth and Planetary Science Letters, 90, 315-329.

JOHNSON, M. R. W. 2002. Shortening budgets and the role of continental subduction during

Kelly, R. K. 2003. Subduction Dynamics at the Middle America Trench: New constraints from swath bathymetry, multichannel seismic data, and 10Be, Ph.D. thesis, Massachusetts Institute of Technology/Woods Hole Oceanographic Institution, pp. 334. 
1091 Khan, M. A., Stern, R. J., Gribble, R. F. \& Windley, B. F. 1997. Geochemical and isotopic constraints on subduction polarity, magma sources, and palaeogeography of the Kohistan intra-oceanic arc, northern Pakistan Himalaya. Journal of the Geological Society, 154, 935-946.

Kimura, G., Silver, E. A., Blum, P. \& ODP Leg 170 Scientific Party 1997. Proceedings of the Ocean Drilling Program, Initial Report, 170, College Station, Texas: Ocean Drilling Program.

Kodaira, S., Iwasaki, T., Urabe, T., Kanazawa, T., Egloff, F., Makris, J. \& SHIMAMURA, H. 1996. Crustal structure across the middle Ryukyu Trench obtained from ocean bottom seismographic data. Tectonophysics, 263, 39-60.

Krebs, W. N., Aleman, A. M., Padilla, H., Rosenfeld, J. H. \& Niemeyer, H. 1992. Age and paleoceanographic significance of the Caleta Herradura diatomite, Peninsula de Mejillones, Antofagasta, Chile. Revista Geologica de Chile, 19, 75-81.

LAMB, S. \& DAVIS, P. 2003. Cenozoic climate change as a possible cause for the rise of the Andes. Nature, 425, 792-797.

Laursen, J., Scholl, D. W. \& von Huene, R. 2002. Neotectonic deformation of the central Chile margin: Deepwater forearc basin formation in response to hot spot ridge and seamount subduction. Tectonics, 21, 1038(5), doi:10.1029/2001TC901023.

Le Pichon, X., Henry, P. \& Lallemant, S. 1993. Accretion and erosion in subduction zones: The role of fluids. Annual Reviews of Earth and Planetary Sciences, 21, , 307-331.

Le Roux, J. P., Gómeza, C. V., Fenner, C. J., Middleton, H., Marchant, M., Buchbinder, B., Frassinetti, D., Marquardt, C., Gregory-Wodzicki, K. M. \& LAVENU, A. 2005. Neogene-Quaternary coastal and offshore sedimentation in north central Chile: Record of sea-level changes and implications for Andean tectonism. Journal of South American Earth Sciences, 19, 83-98.

Lee, J. C., Chu, H.-T., Angelier, J., Chan, Y.-C., Hu, J.-C., Lu, C.-Y. \& RAU, R.-J. 2002. Geometry and structure of northern surface ruptures of the $1999 \mathrm{Mw}=7.6 \mathrm{Chi}-\mathrm{Chi}$, Taiwan earthquake: influence from inherited fold belt structures. . Journal of Structural Geology, 24, 173-192.

LeEch, M. \& Stockli, D. F. 2000. The late exhumation history of the ultrahigh-pressure Maksyutov Complex, south Ural Mountains, from new apatite fission track data. Tectonics, 19(1), 153-167. 
1123 Leeman, W. P., CARr, M. J. \& Morris, J. D. 1994. Boron geochemistry of the Central 1124 American volcanic arc; constraints on the genesis of subduction-related magmas. 1125 Geochimica et Cosmochimica Acta, 58, 149-168.

1126 Lin, A. T., Watts, A. B. \& Hesselbo, S. P. 2003. Cenozoic stratigraphy and subsidence 1127 history of the South China Sea margin in the Taiwan region. Basin Research, 15, 453-478.

1128 LiU, T. K., Chen, Y. G., Chen, W. S. \& JiAnG, S. H. 2000. Rates of cooling and denudation 1129 of the Early Penglai Orogeny, Taiwan, as assessed by fission-track constraints. 1130 Tectonophysics, 320, 69-82.

1131 LundBerg, N., ReED, D. L., LiU, C.-S. \& LieSKe, J. 1997. Forearc-basin closure and arc 1132 accretion in the submarine suture zone south of Taiwan. Tectonophysics, 274, 5-23.

1133 Marquardt, C., Lavenu, A., Ortlieb, L., Godoya, E. \& Comte, D. 2004. Coastal 1134 neotectonics in southern Central Andes; uplift and deformation of marine terraces in 1135 northern Chile $\left(27^{\circ} \mathrm{S}\right)$. Tectonophysics, 394, 193-219.

1136 McLennan, S. M. \& TAYLOR, S. R. 1982. Geochemical constraints on the growth of the 1137 continental crust. Journal of Geology, 90, 347-361.

1138 Melnick, D. \& ECHTLER, H. P. 2006. Inversion of forearc basins in south-central Chile caused by rapid glacial age trench fill. Geology, 34, 709-712.

1140 Meschede, M., Zweigel, P. \& Kiefer, E. 1999. Subsidence and extension at a convergent 1141 plate margin: Evidence for subduction erosion off Costa Rica,. Terra Nova, 11, 112- 117.

1142 Metivier, F., Gaudemer, Y., TApponnier, P. \& Klein, M. 1999. Mass accumulation rates 1143 in Asia during the Cenozoic. Geophysical Journal International, 137(2), 280-318.

1144 Miller, H. 1970. Vergleichende Studien an praemesozoischen Gesteinen Chiles unter 1145 besonderer Beruecksichtigung ihrer Kleintektonik. Stuttgart: Schweizerbart'sche 1146 Verlagsbuchhandlung, p. 36,

1147 Milliman, J. D. 1997. Fluvial sediment discharge to the sea and the importance of regional 1148 tectonics. In Tectonic Uplift and Climate Change. (Ed, W. F. RudDIMAN), New York: 1149 Plenum Press, pp. 239-257.

1150 Moorbath, S. 1978. Age and isotope evidence for the evolution of the continental crust. 1151 Philosophical Transactions of the Royal Society, London, A, 288, 401-413.

1152 Morris, J., VALENTINE, R. \& HARrison, T. 2002. 10Be imaging of sediment accretion and 1153 subduction along the northeast Japan and Costa Rica convergent margins. Geology, 30, $1154 \quad 59-62$. 
Mountain, G. S. \& Prell, W. L. 1990. A multiphase plate tectonic history of the southeast continental margin of Oman. In The Geology and Tectonics of Oman. (Eds, A. H. F. Robertson, M. P. Searle and A. C. Ries), London: Geological Society, Special Publication, 49, pp. 725-743.

MURAUCHI, S. 1971. The renewal of island arcs and the tectonics of marginal seas. In Island arc and marginal seas. (Eds, S. AsANO and G. B. UdINTSEV), Japan: Tokai University Press, pp. 39-56.

NiSBET, E. G. 1987. The young Earth; an introduction to Archaean geology. London: Allen \& Unwin, p. 402,

O’Nions, R. K., Evensen, N. M. \& Hamilton, P. J. 1979. Geochemical modelling of mantle differentiation and crustal growth. Journal of Geophysical Research, 84, 60916101.

Ortlieb, L., Zazo, C., Goy, J. L., Dabrio, C. \& Macharé, J. 1996. Pampa del Palo; an anomalous composite marine terrace on the uprising coast of southern Peru. Journal of South American Earth Sciences, 9, 367-379.

Patino, L. C., CARr, M. J. \& Feigenson, M. D. 2000. Local and regional variations in Central American arc lavas controlled by variations in subducted sediment input. Contributions to Mineralogy and Petrology, 138, 265-283.

PENG, T.-H., LI, Y.-H. \& WU, F. T. 1977. Tectonic uplift rates of the Taiwan Island since the early Holocene. Geological Society of China Memoir, 2, 57-69.

Plank, T. \& LANGMUiR, C. H. 1988. An evaluation of the global variations in the major element chemistry of arc basalts. Earth and Planetary Science Letters, 90, 349-370.

Platt, J. P. 1986. The mechanics of frontal imbrication: A first-order analysis. Geologische Rundschau, 77, 577-589.

Ranero, C. R. \& von Huene, R. 2000. Subduction erosion along the Middle America convergent margin. Nature, 404(6779), 748-752.

Ratschbacher, L., Hacker, B. R., Webb, L. E., McWilliams, M., Ireland, T., Dong, S., Calvert, A., Chateigner, D. \& Wenk, H.-R. 2000. Exhumation of the ultrahighpressure continental crust in east central China; Cretaceous and Cenozoic unroofing and the Tan-Lu Fault. Journal of Geophysical Research, 105(B6), 13,303-13,338. 
1185 Reagan, M., Morris, J., Herrstrom, E. \& Murrell, M. 1994. Uranium series and beryllium isotopic evidence for an extended history of subduction modification of the mantle below Nicaragua. Geochimica et Cosmochimica Acta, 58, 4199-4212.

RUDNICK, R. L. 1995. Making continental crust. Nature, 378, 573-578.

RUDNICK, R. L. \& FounTAIN, D. M. 1995. Nature and composition of the continental crust; a lower crustal perspective. Reviews of Geophysics, 33(267-309).

RUTLAND, R. W. R. 1971. Andean orogeny and ocean floor spreading. Nature, 233, 252-255.

RYAN, H. F. \& SCHOLL, D. W. 1993. Geologic implications of great interplate earthquakes along the Aleutian arc. Journal of Geophysical Research, 98(B12), 22,135-22,146.

Scheuber, E. \& Reutter, K. J. 1992. Magmatic arc tectonics in the Central Andes between $21^{\circ}$ and $25^{\circ} \mathrm{S}$. Tectonophysics, 205, 127-140, doi: 10.1016/0040-1951(92)90422-3.

Scholl, D. W., Marlow, M. S. \& CoOper, A. K. 1977. Sediment subduction and offscraping at Pacific margins. In: (eds.) Island arcs, deep sea trenches and back-arc basins. (Eds, M. Talwani and W. C. Pitman): American Geophysical Union, Maurice Ewing Series, 1, pp. 199-210.

Schubert, G. \& Reymer, A. P. S. 1985. Continental volume and freeboard through geological time. Nature, 316, 336-339.

Shipley, T. H., McIntosh, K. D., Silver, E. A. \& StoffA, P. L. 1992. Three-dimensional imaging of the Costa Rica accretionary prism: Structural diversity in a small volume of the lower slope. Journal of Geophysical Research, 97, 4439-4459.

Sibuet, J.-C. \& HsU, S.-K. 1997. Geodynamics of the Taiwan arc -arc collision. Tectonophysics, 274, , 221-251.

SonG, S.-R. \& LO, H.-J. 2002. Lithofacies of volcanic rocks in the central Coastal Range, eastern Taiwan; implications for island arc evolution. Journal of Asian Earth Sciences, 21, 23-38.

Stein, M. \& Hofmann, A. W. 1994. Mantle plumes and episodic crustal growth. Nature,

1212 Stern, C. R. 2004. Active Andean volcanism: its geologic and tectonic setting. Revista 1213 Geologica de Chile, 31, 161-206.

1214 Stern, R. J. \& Bloomer, S. H. 1992. Subduction zone infancy: examples from the Eocene 1215 Izu-Bonin-Mariana and Jurassic California arcs. . Geological Society of America Bulletin, $1216 \quad \mathbf{1 0 4}, 1621-1636$. 
1217 SuPPE, J. 1981. Mechanics of mountain building and metamorphism in Taiwan. Geological 1218 Society of China, Memoir, 4, pp. 67-89.

1219 SUPPE, J. 1984. Kinematics of arc-continent collision, flipping of subduction, and backarc spreading near Taiwan. In A special volume dedicated to Chun-Sun Ho on the occasion of his retirement. (Ed, S. F. TSAN), Geological Society of China Memoir, 6, pp. 21-33.

Suyehiro, K., Takahashi, N., Arile, Y., Yokoi, Y., Hino, R., Shinohara, M., Kanazawa, T., Hirata, N., Tokuyama, H. \& TAira, A. 1996. Continental crust, crustal underplating, and low-Q upper mantle beneath an oceanic island arc. Science, 272, 390392.

TAYLOR, S. R. \& MCLENNAN, S. M. 1995. The geochemical evolution of the continental crust. Reviews of Geophysics, 33, 241-265.

TENG, L. S. 1990. Geotectonic evolution of late Cenozoic arc-continent collision in Taiwan. Tectonophysics, $\mathbf{1 8 3}, 57-76$.

TEnG, L. S. 1996. Extensional collapse of the northern Taiwan mountain belt. Geology, 24, 949-952.

TEnG, L. S., LEE, C.-T., Tsai, Y.-B. \& HSIAO, L.-Y. 2000. Slab breakoff as a mechanism for flipping of subduction polarity in Taiwan. Geology, 28, 155-158.

Treloar, P. J., Petterson, M. G., Jan, M. Q. \& Sullivan, M. A. 1996. A re-evaluation of the stratigraphy and evolution of the Kohistan arc sequence, Pakistan Himalaya: Implications for magmatic and tectonic arc-building processes. Journal of the Geological Society, 153, 681-693.

TsaO, S. H., Li, T.-C., Tien, J.-L., Chen, C.-H., LiU, T.-K. \& Chen, C.-H. 1992. Illite crystallinity and fission track ages along the east central cross-island highway of Taiwan. Acta Geologica Taiwanica, 30, 45-64.

TsuCHI, R. 1992. Neogene events in Japan and on the Pacific coast of South America. Revista Geologica de Chile, 19, 67-73.

Valentine, R. B., Morris, J. D., Duncan, D., JR. \& ODP Scientific PARTy LeG 1701997. Sediment subduction, accretion, underplating and arc volcanism along the margin of Costa Rica: Constraints from $\mathrm{Ba}, \mathrm{Zn}, \mathrm{Ni}$, and 10Be concentrations. Eos, Transactions, American Geophysical Union, 78, 673.

Vannucchi, P., Scholl, D. W., Meschede, M. \& McDougall-Reid, K. 2001. Tectonic erosion and consequent collapse of the Pacific margin of Costa Rica: Combined 
implications from ODP Leg 170, seismic offshore data, and regional geology of the Nicoya Peninsula. Tectonics, 20(5), 649-668.

Vannucchi, P., Ranero, C. R., Galeotti, S., Straub, S. M., Scholl, D. W. \& McDougall-Ried, K. 2003. Fast rates of subduction erosion along the Costa Rica Pacific margin: Implications for nonsteady rates of crustal recycling at subduction zones. Journal of Geophysical Research-Solid Earth, 108, 2511(B11), doi:10.1029/2002JB002207.

Vannucchi, P., Galeotti, S., Clift, P. D., Ranero, C. R. \& von Huene, R. 2004. Longterm subduction-erosion along the Guatemalan margin of the Middle America Trench. Geology, 32(7), 617-620.

Vannucchi, P., Remitti, F. \& Bettelli, G. 2008. Geological record of fluid flow and seismogenesis along an erosive subducting plate boundary. Nature, 451, 699-704, doi:10.1038/nature06486.

ViTA-FinZI, C. \& Lin, J. C. 1998. Serial reverse and strike slip on imbricate faults: The Coastal Range of east Taiwan. Geology, 26, 279-282.

von Huene, R., Langseth, M., Nasu, N. \& OKadA, H. 1982. A summary of Cenozoic tectonic history along the IPOD Japan trench transect. Geological Society of America Bulletin, 93, 829-846.

VON Huene, R. \& LEE, H. 1982. The possible significance of pore fluid pressures in subduction zones. In Studies in Continental Margin Geology. (Eds, J. S. WATKINS and C. L. DRAKE): American Association of Petroleum Geologists, Memoir, 34, pp. 781-791.

von Huene, R. \& Scholl, D. W. 1991. Observations at Convergent Margins Concerning Sediment Subduction, Subduction Erosion, and the Growth of Continental-Crust. Reviews of Geophysics, 29(3), 279-316.

von Huene, R. \& Ranero, C. R. 2003. Subduction erosion and basal friction along the sediment-starved convergent margin off Antofagasta, Chile. Journal of Geophysical Research, 108, 2079(B2), doi:10.1029/2001JB001569.

VON Huene, R., RANERO, C. \& VANNUCCHI, P. 2004. Generic model of subduction erosion. Geology, 32, 913-916.

WANG, T.-K., LiN, S.-F., LIU, C.-S. \& WANG, C.-S. 2004. Crustal structure of southernmost Ryukyu subduction zone; OBS, MCS and gravity modelling. Geophysical Journal International, 157, 147-163. 
1280 Wells, R. E., Blakely, R. J., Sugiyama, Y., Scholl, D. W. \& Dinterman, P. A. 2003. 1281 Basin-centered asperities in great subduction zone earthquakes: A link between slip, 1282 subsidence, and subduction erosion? Journal of Geophysical Research, 108(B10), 1283 doi:10.1029/2002JB002072.

1284 Willett, S., Beaumont, C. \& Fullsack, P. 1993. Mechanical model for the tectonics of 1285 doubly vergent compressional orogens. Geology, 21, 371-374.

1286 Willett, S. D., Fisher, D., Fuller, C., ChaO, Y.-E. \& YU, L.-C. 2003. Erosion rates and 1287 orogenic-wedge kinematics in Taiwan inferred from fission-track thermochronometry. 1288 Geology, 31(11), 945-948.

1289 WiSE, D. U. 1974. Continental margins, freeboard and the volumes of continents and oceans 1290 through time. In The Geology of Continental Margins. (Eds, C. A. BuRK and C. L. 1291 DRAKE), New York: Springer-Verlag, pp. 45-58.

1292 Zhang, P., Molnar, P. \& Downs, W. R. 2001. Increased sedimentation rates and grain 1293 sizes 2-4 Myr ago due to the influence of climate change on erosion rates. Nature, 410, 1294 891-897.

1295

1296 


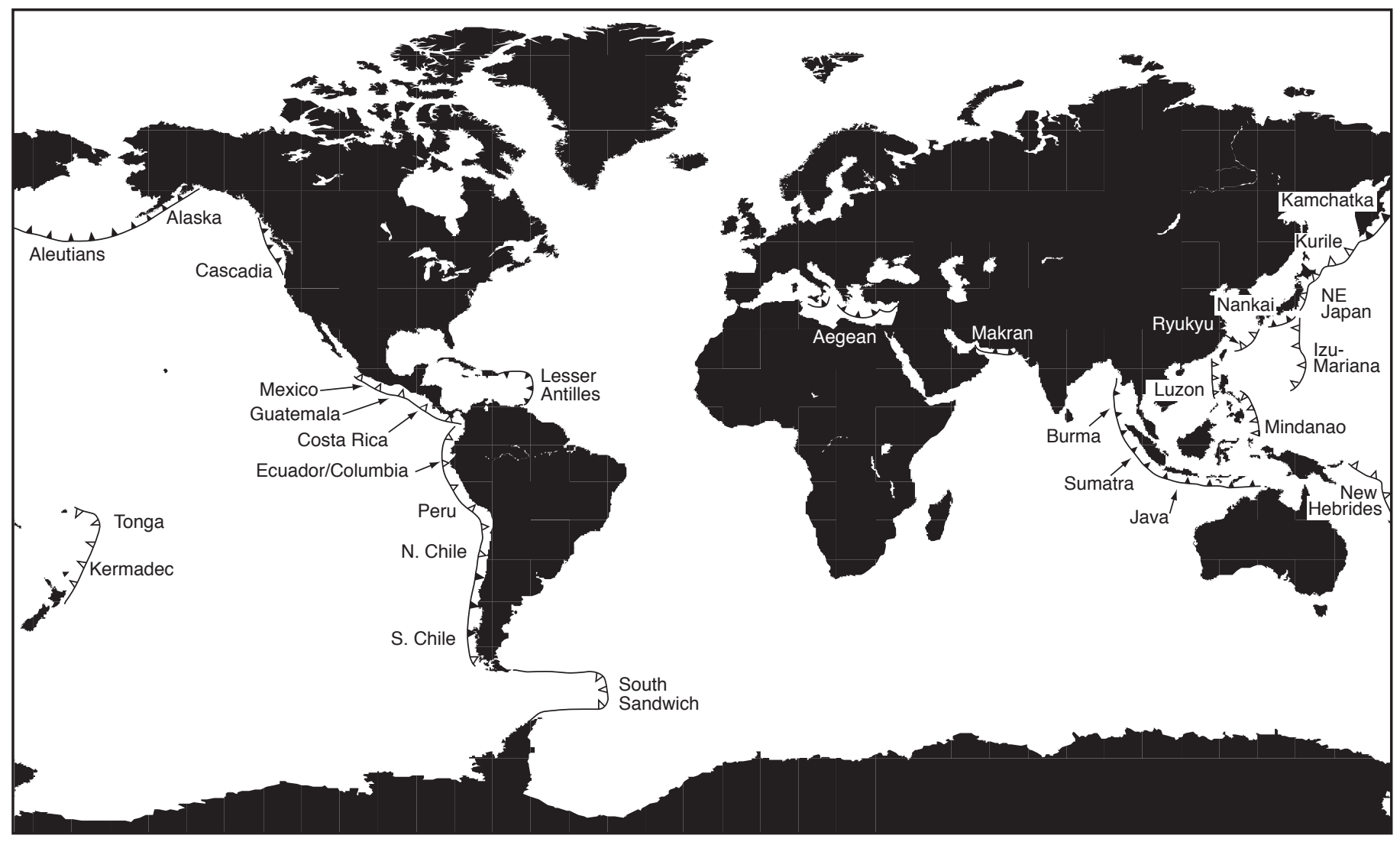

Figure 1

Clift et al. 

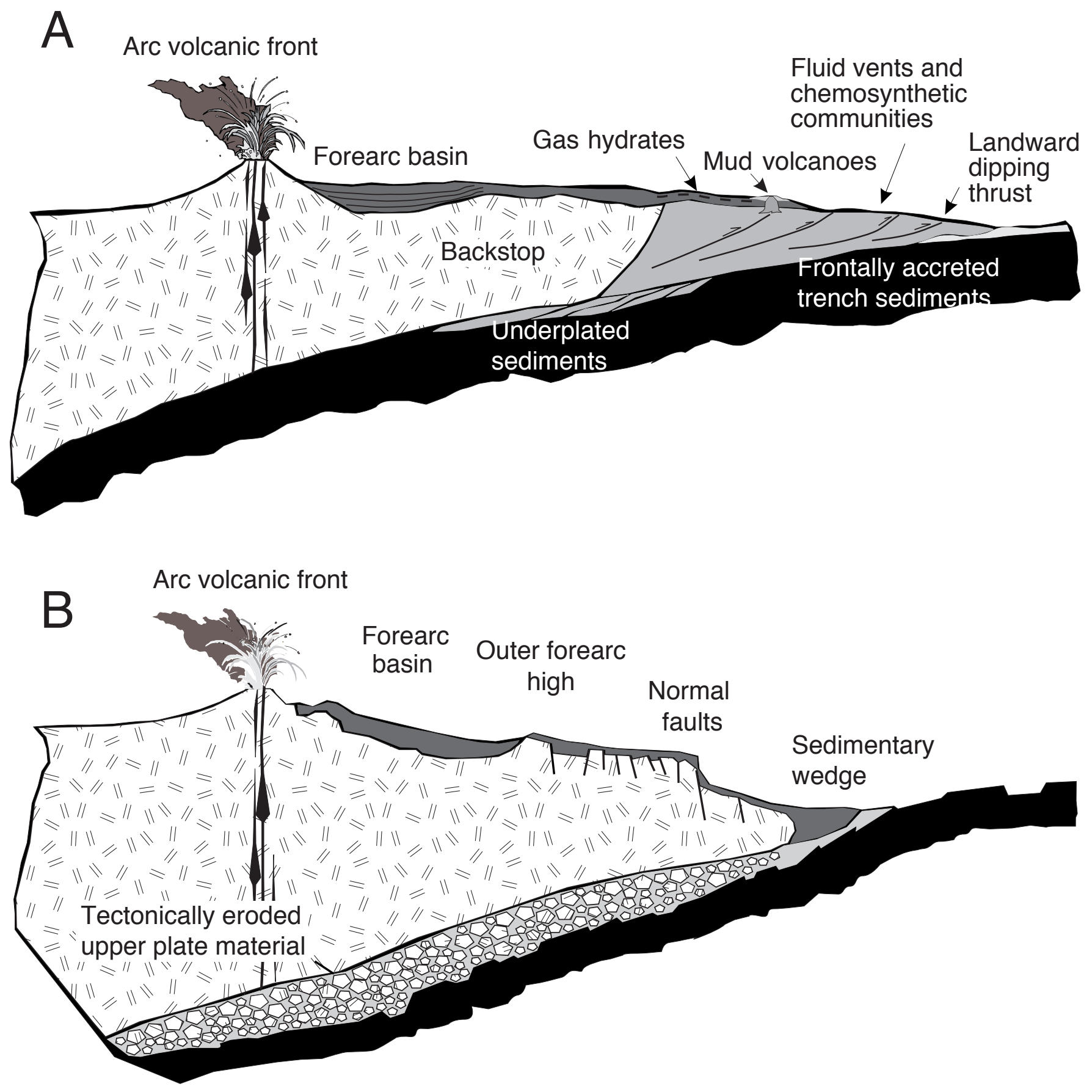

Figure 2

Clift et al. 
A

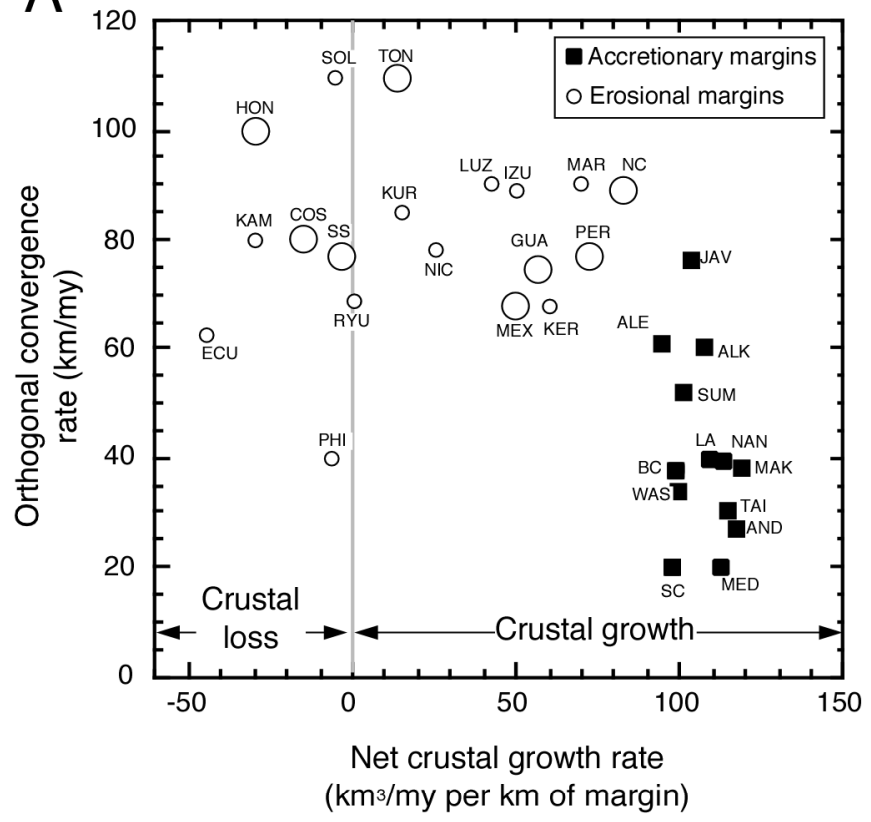

B

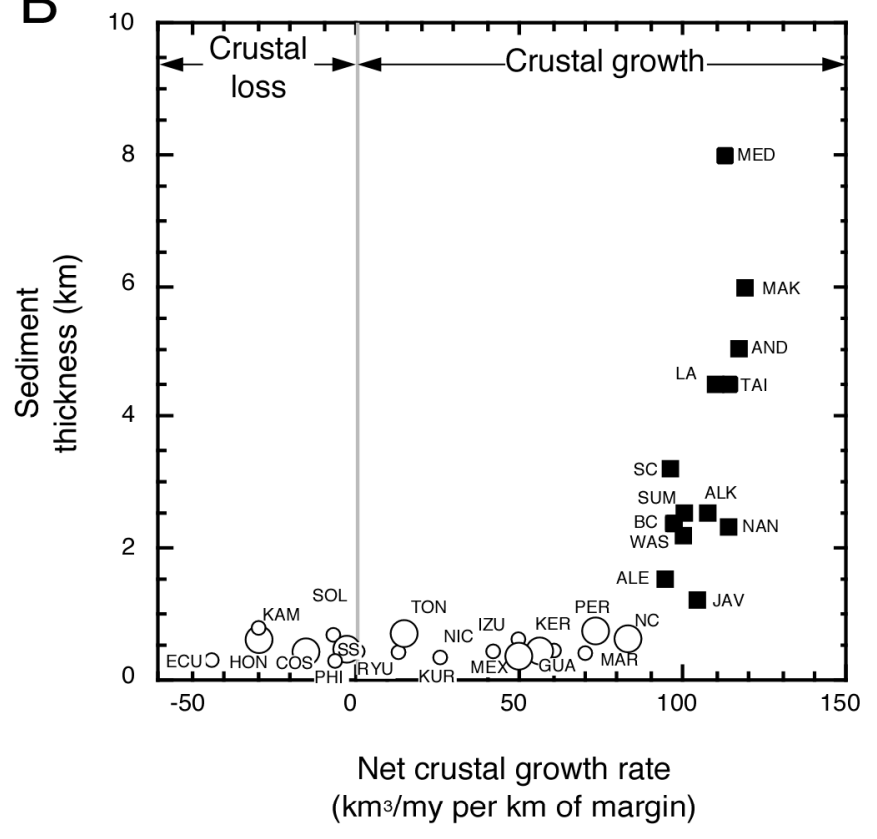

Figure 3

Clift et al. 

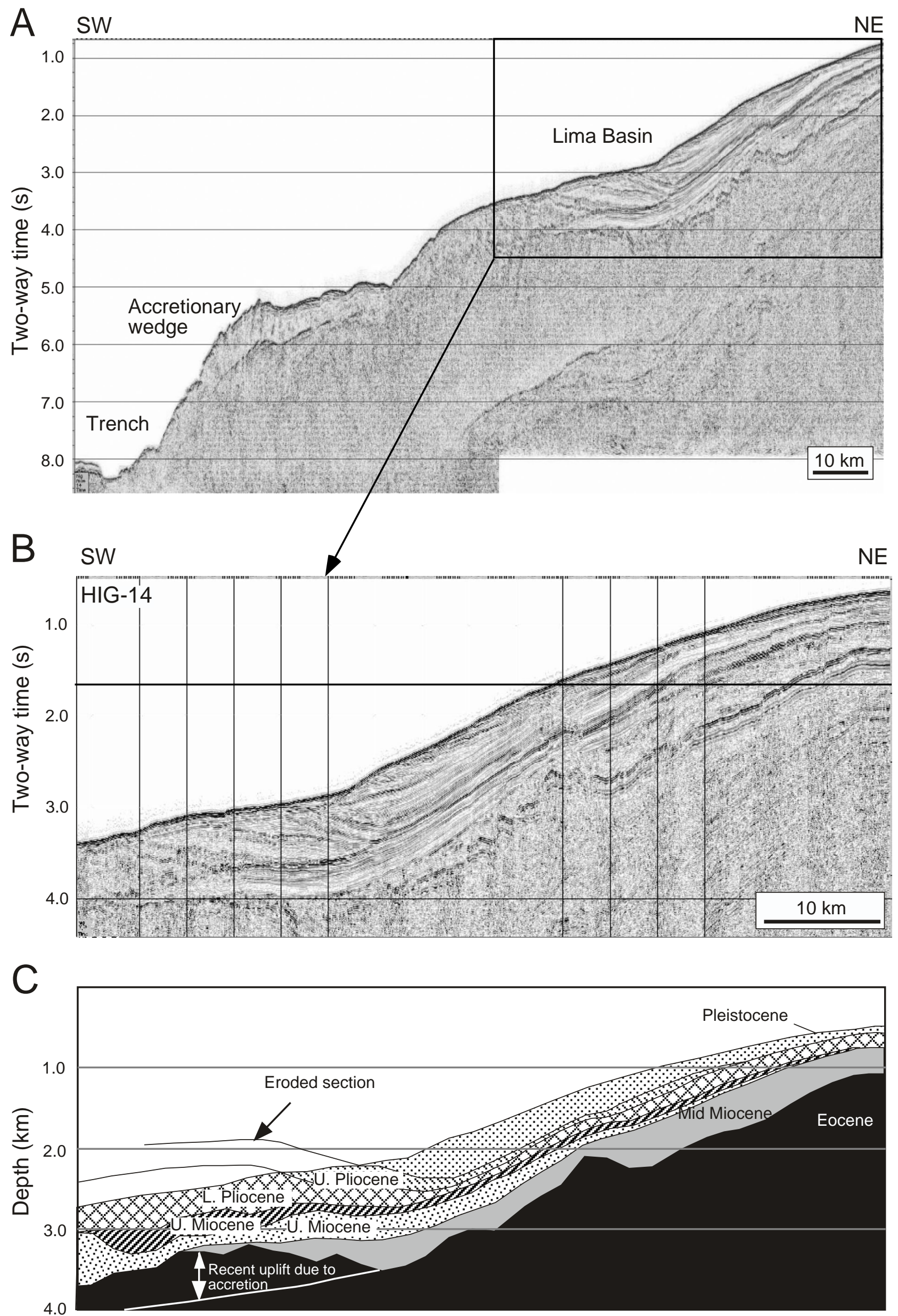

Figure 4

Clift et al. 


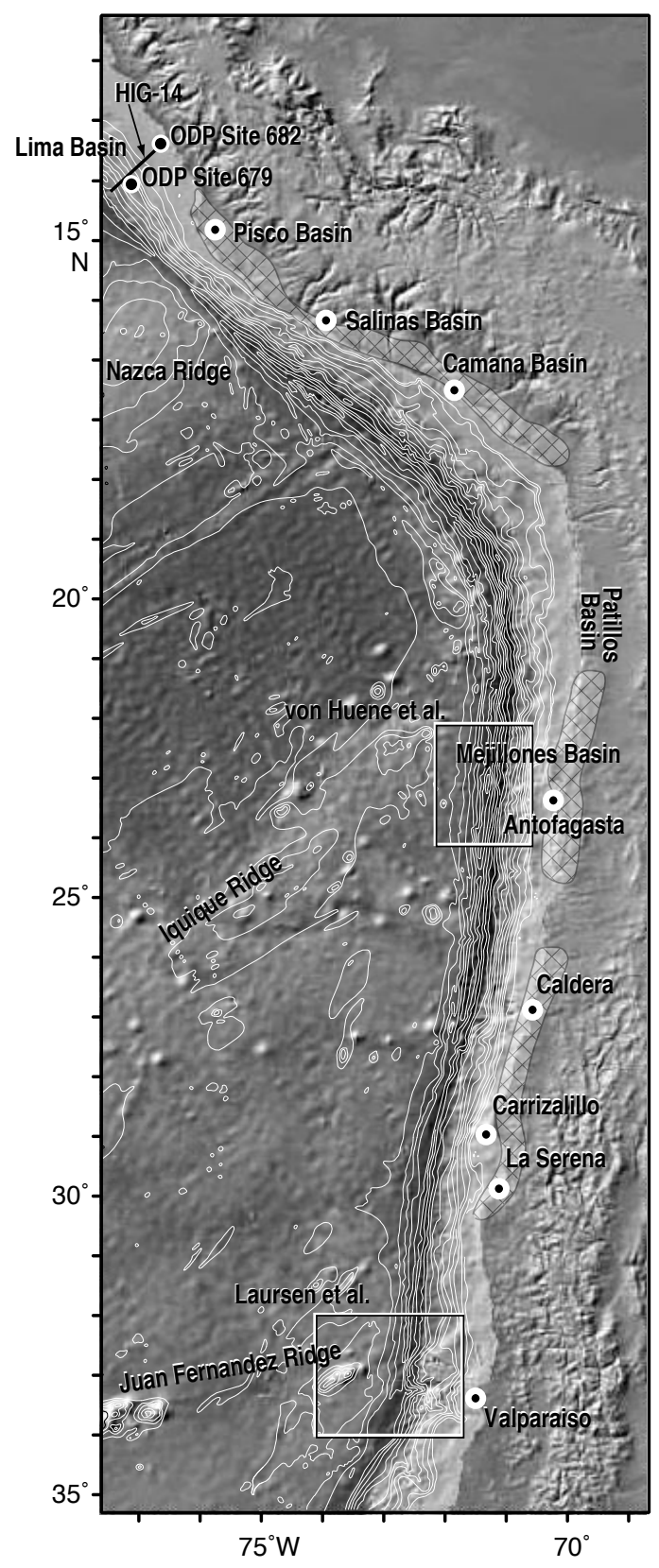

Figure 5

Clift et al. 


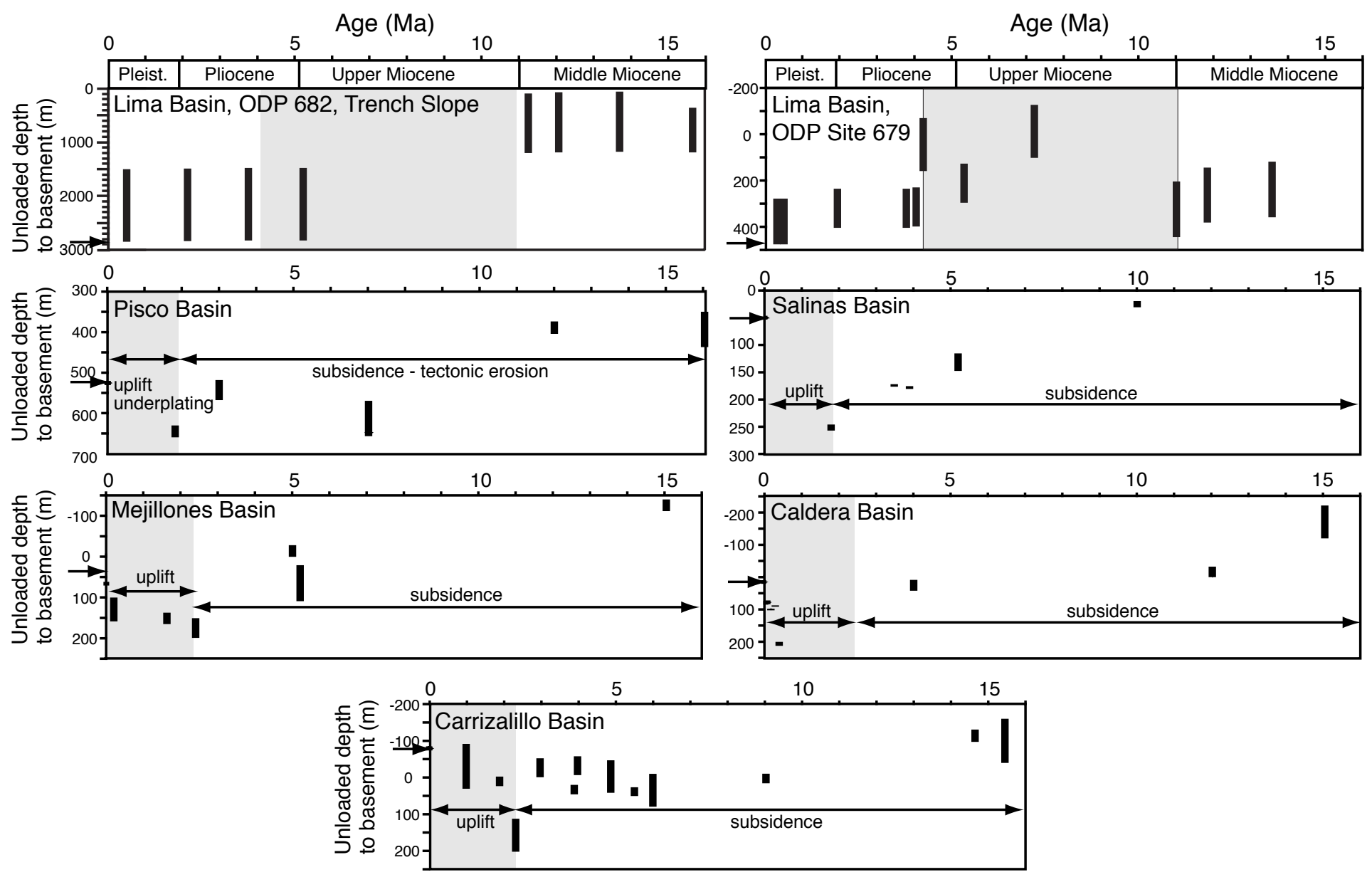

Figure 6

Clift et al. 

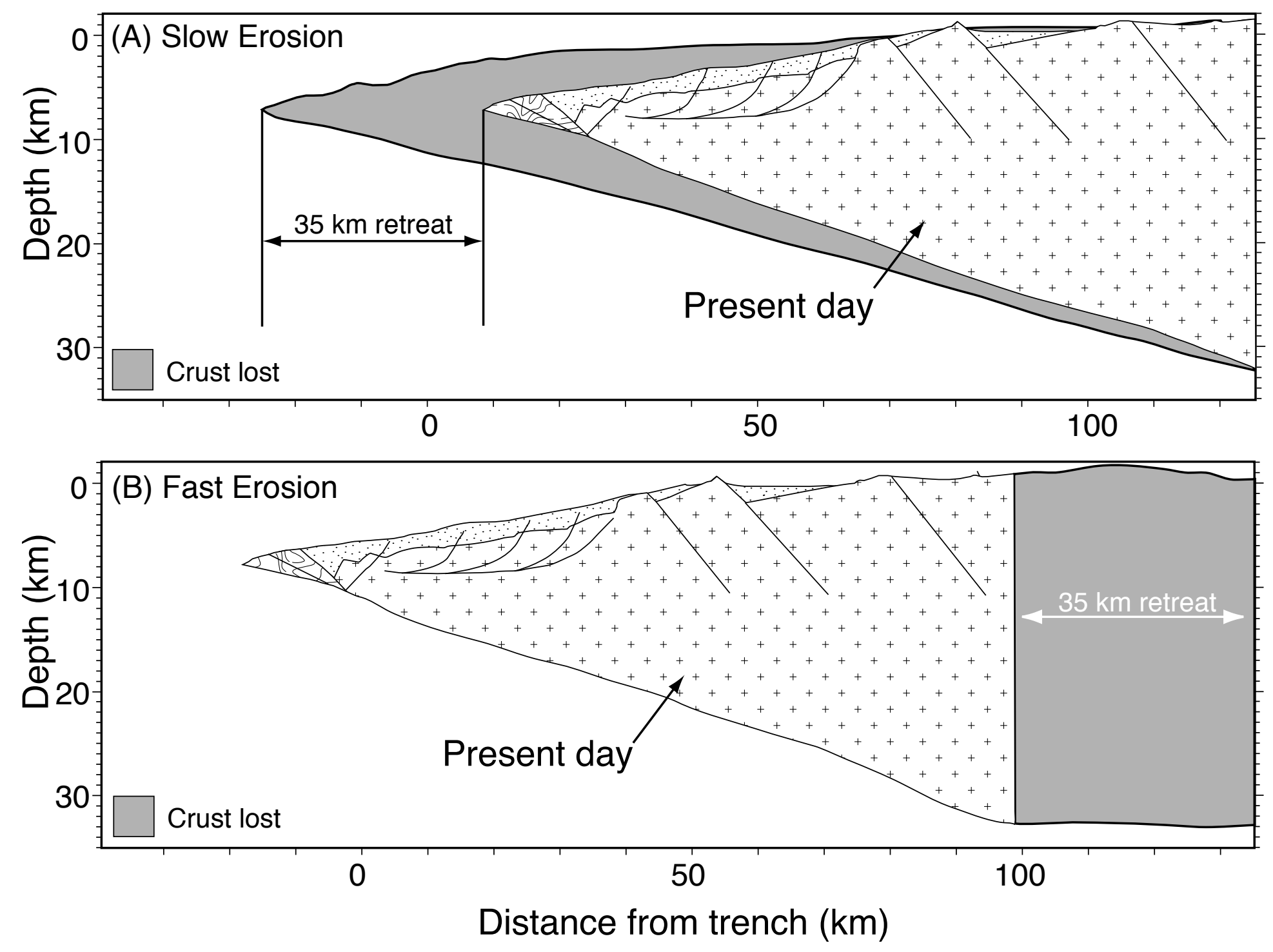

Figure 7

Clift et al. 

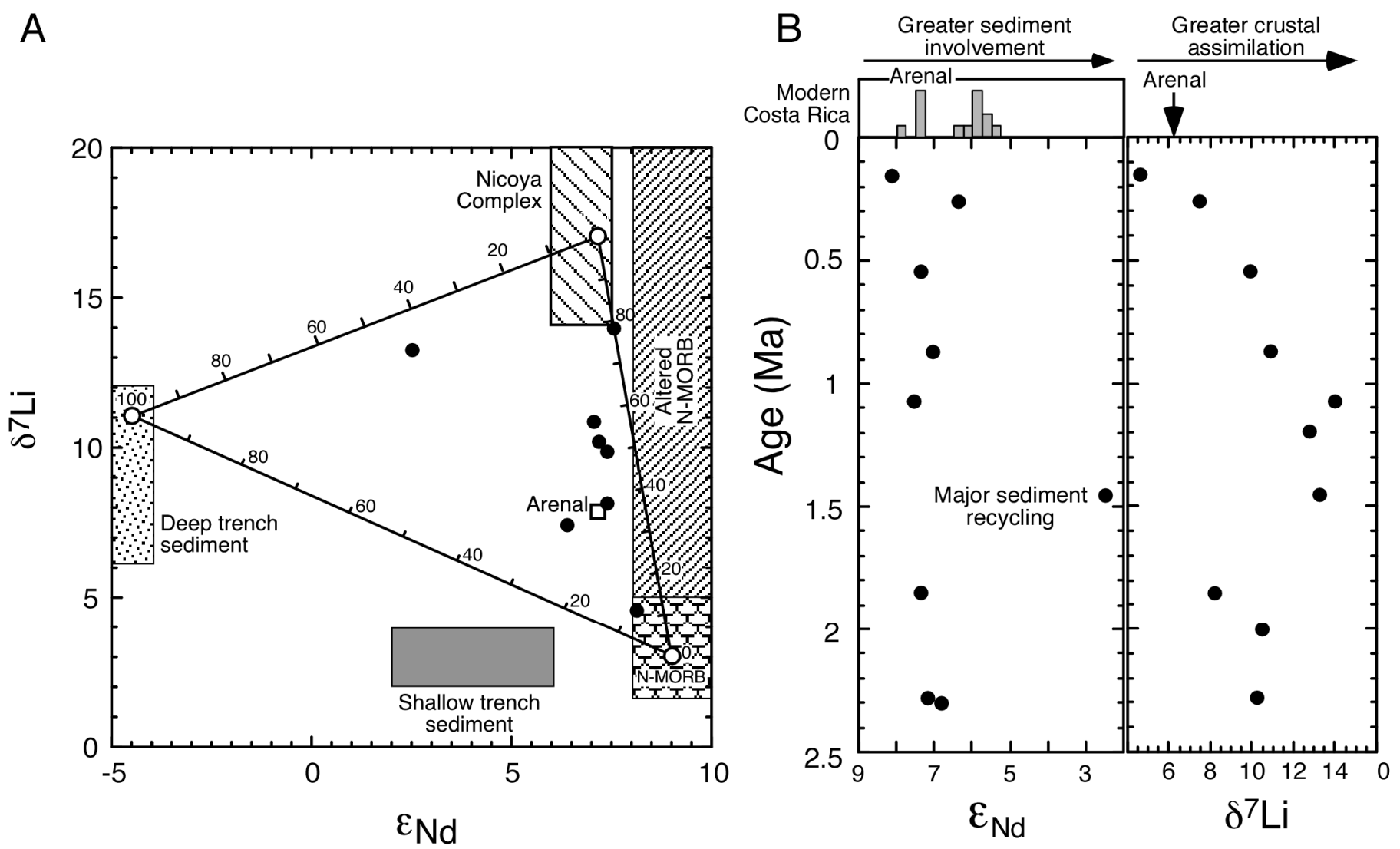

Figure 8

Clift et al. 


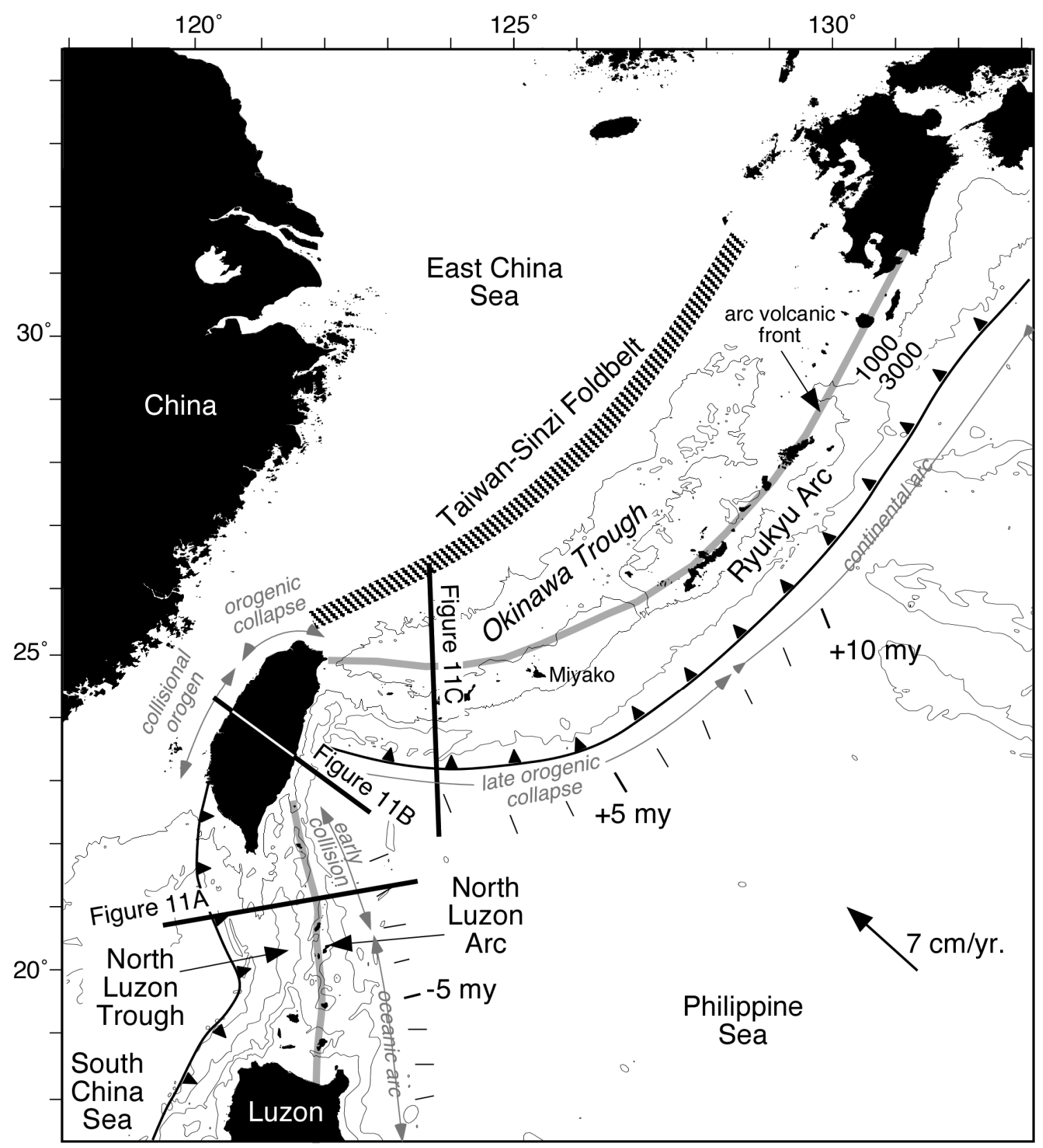

Figure 9

Clift et al. 


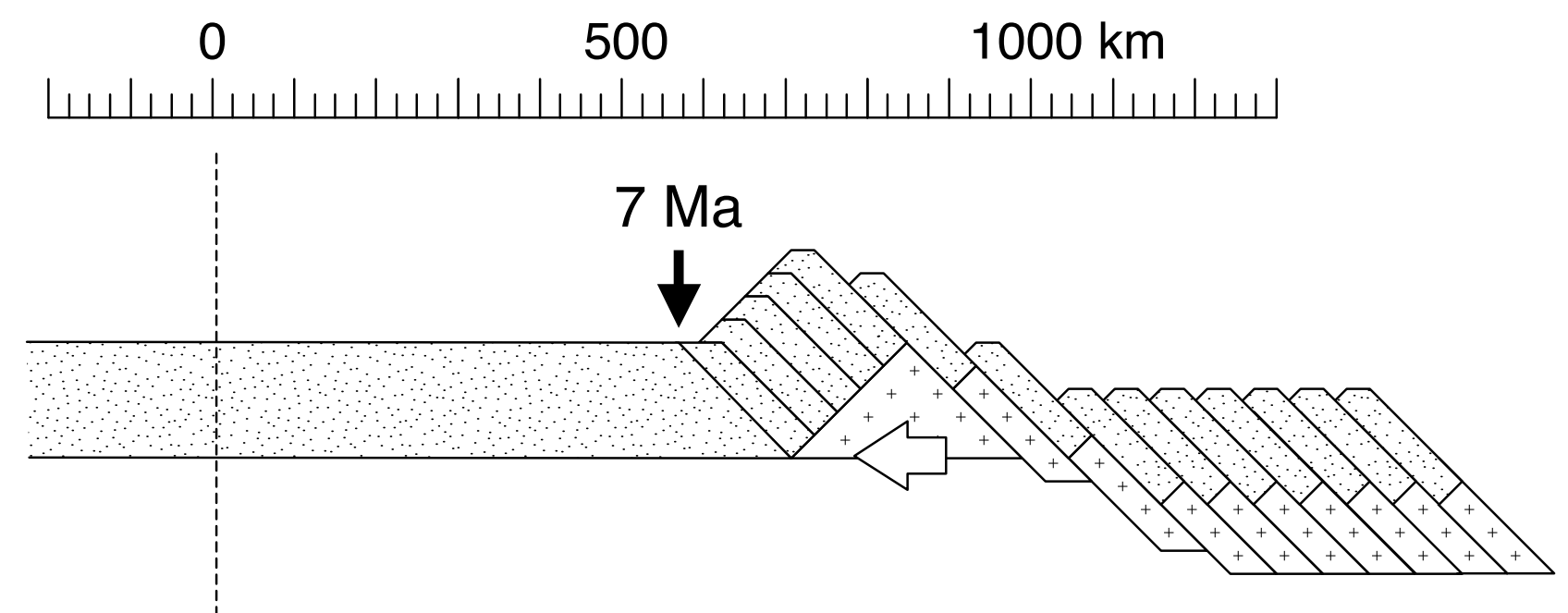

\section{$3.5 \mathrm{Ma}$}
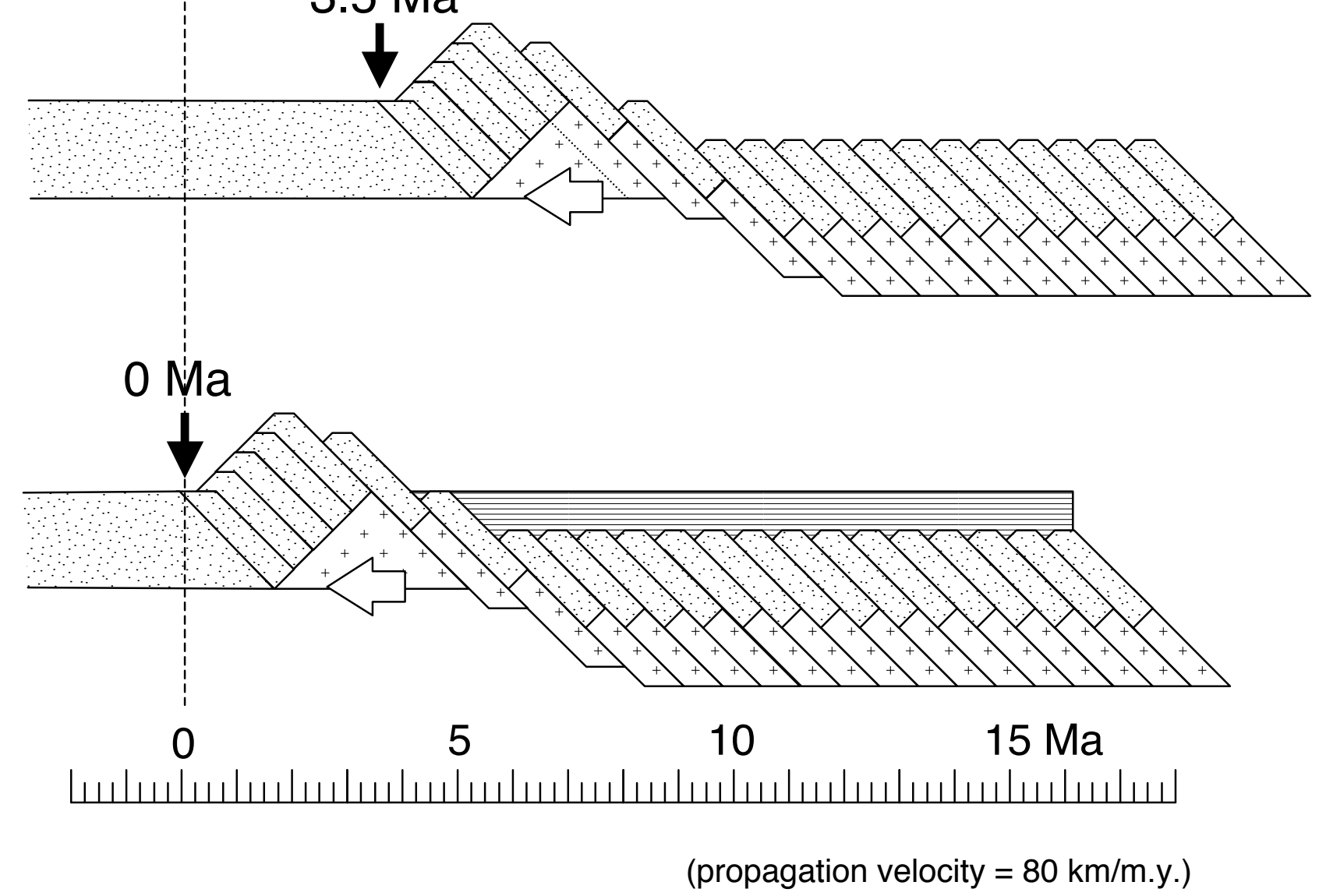

Figure 10

Clift et al. 
(A) South of Taiwan, Luzon Arc

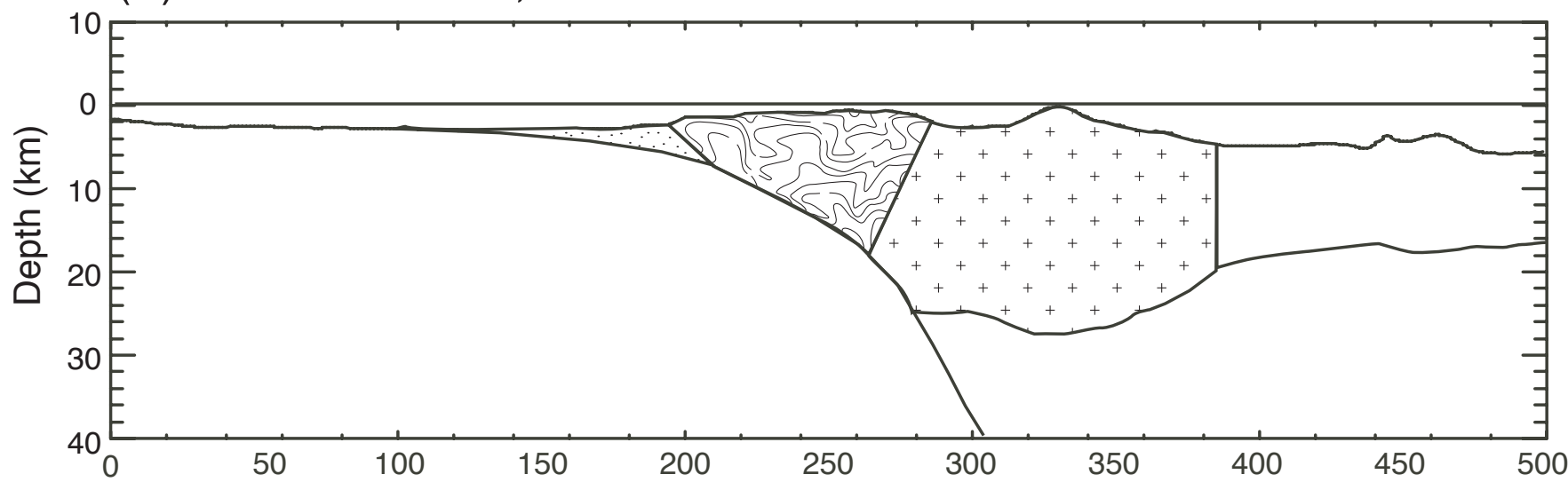

(B) Central Taiwan

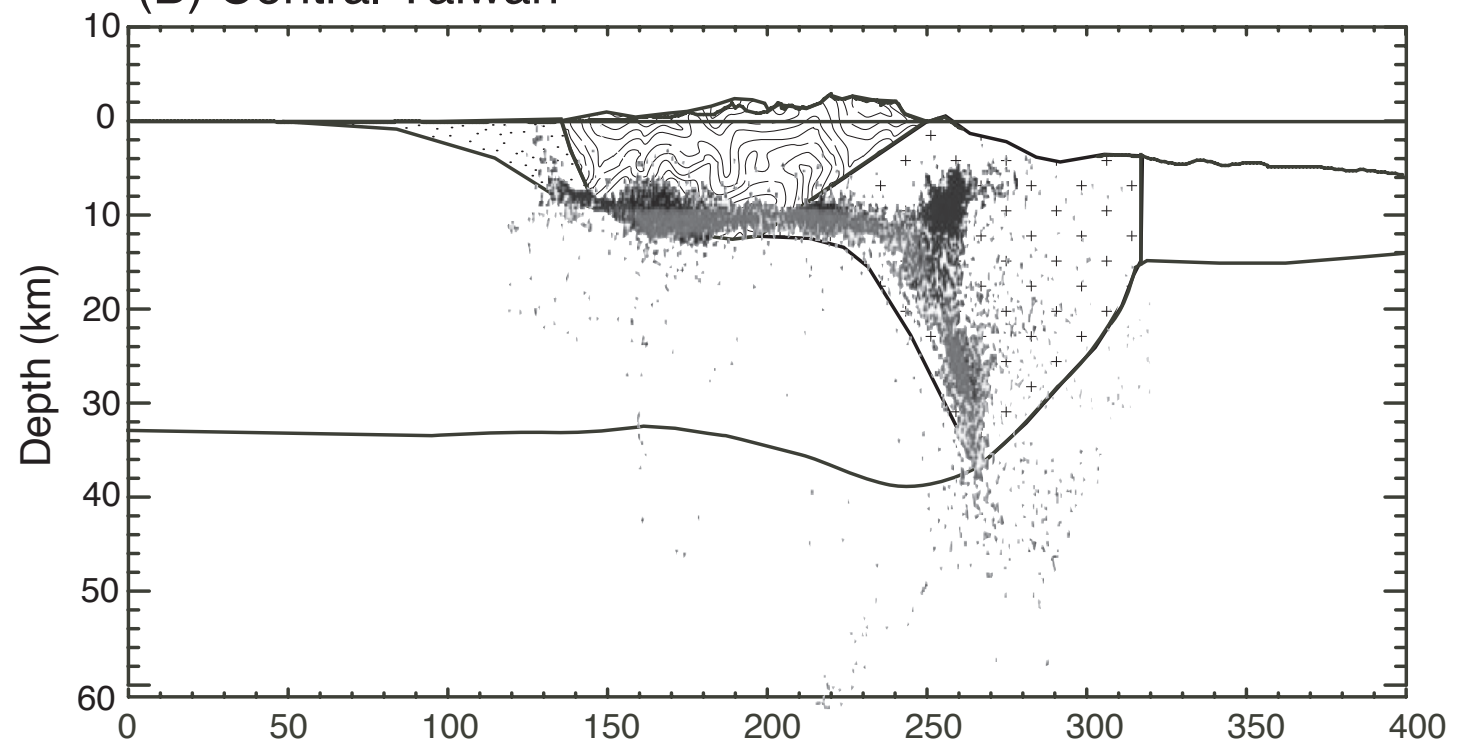

(C) Ryukyu Arc-Okinawa Trough

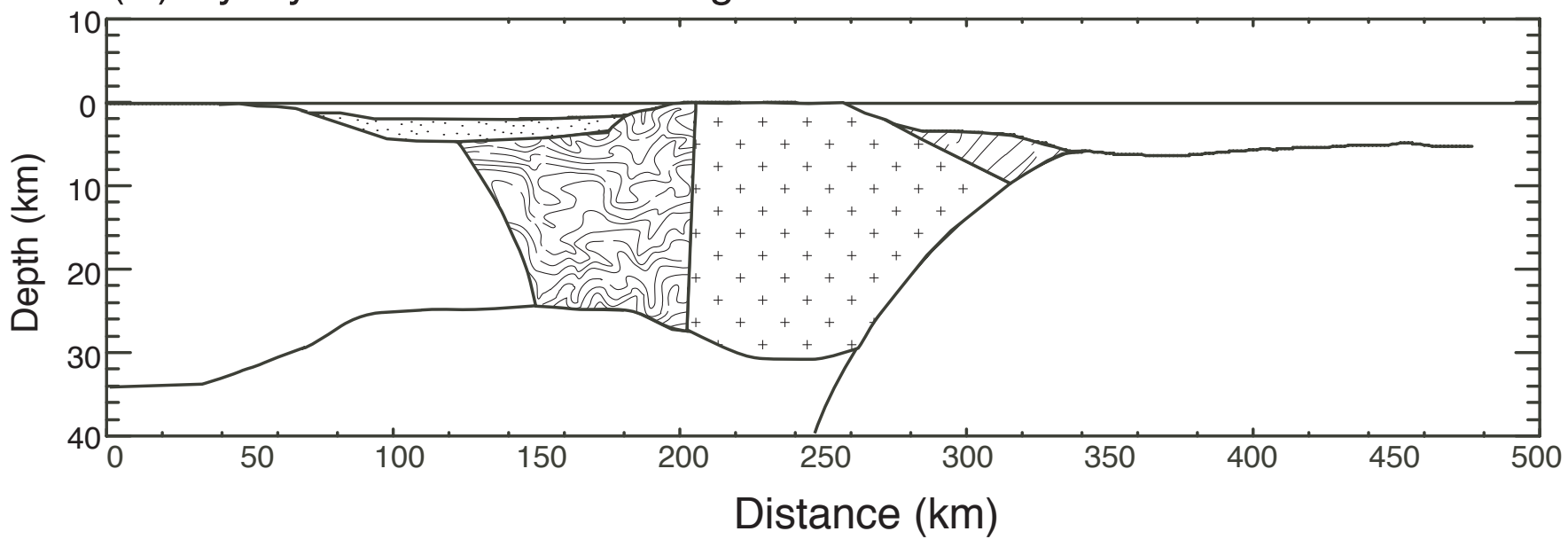

Figure 11

Clift et al. 


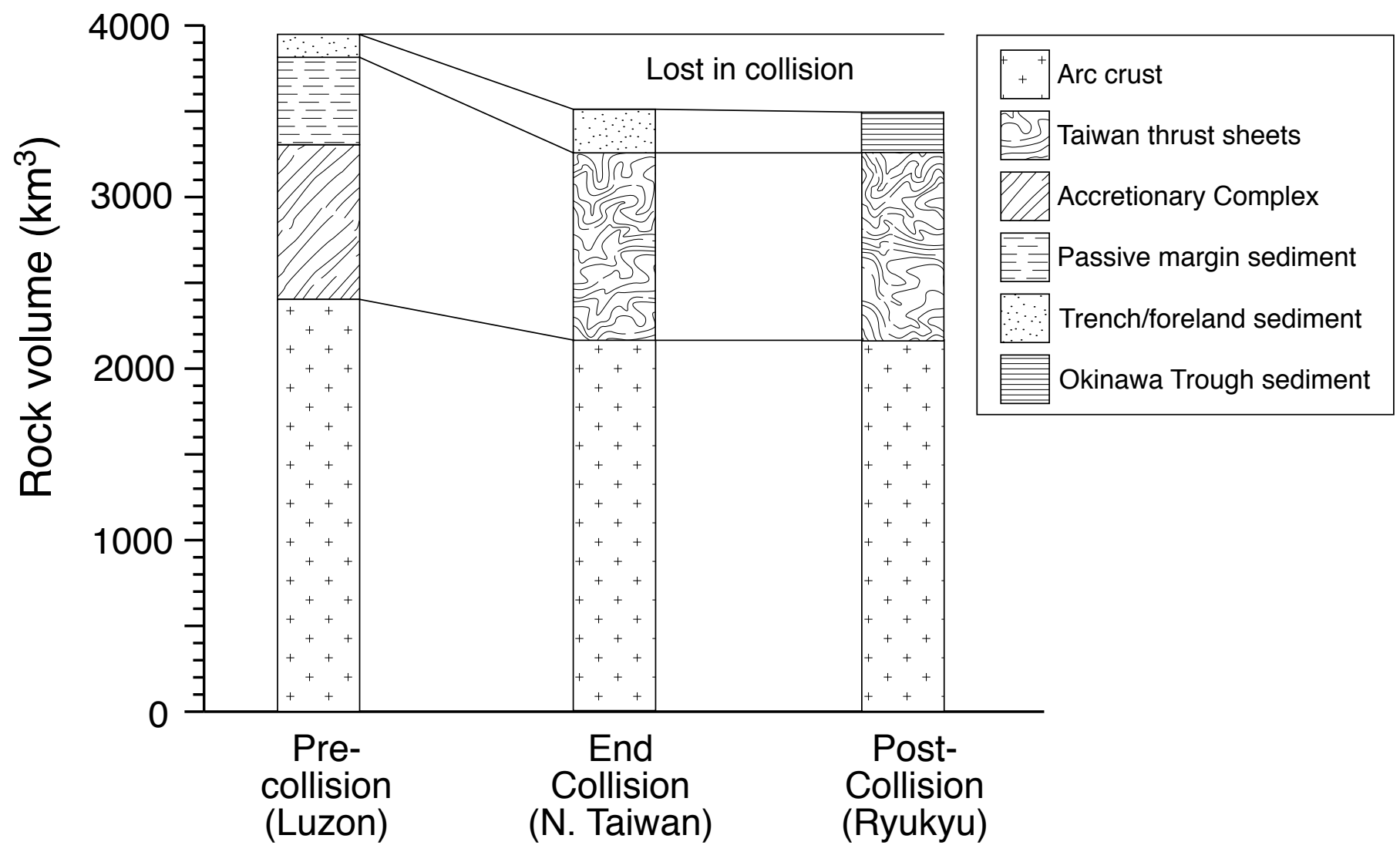

Figure 12

Clift et al. 
(A)

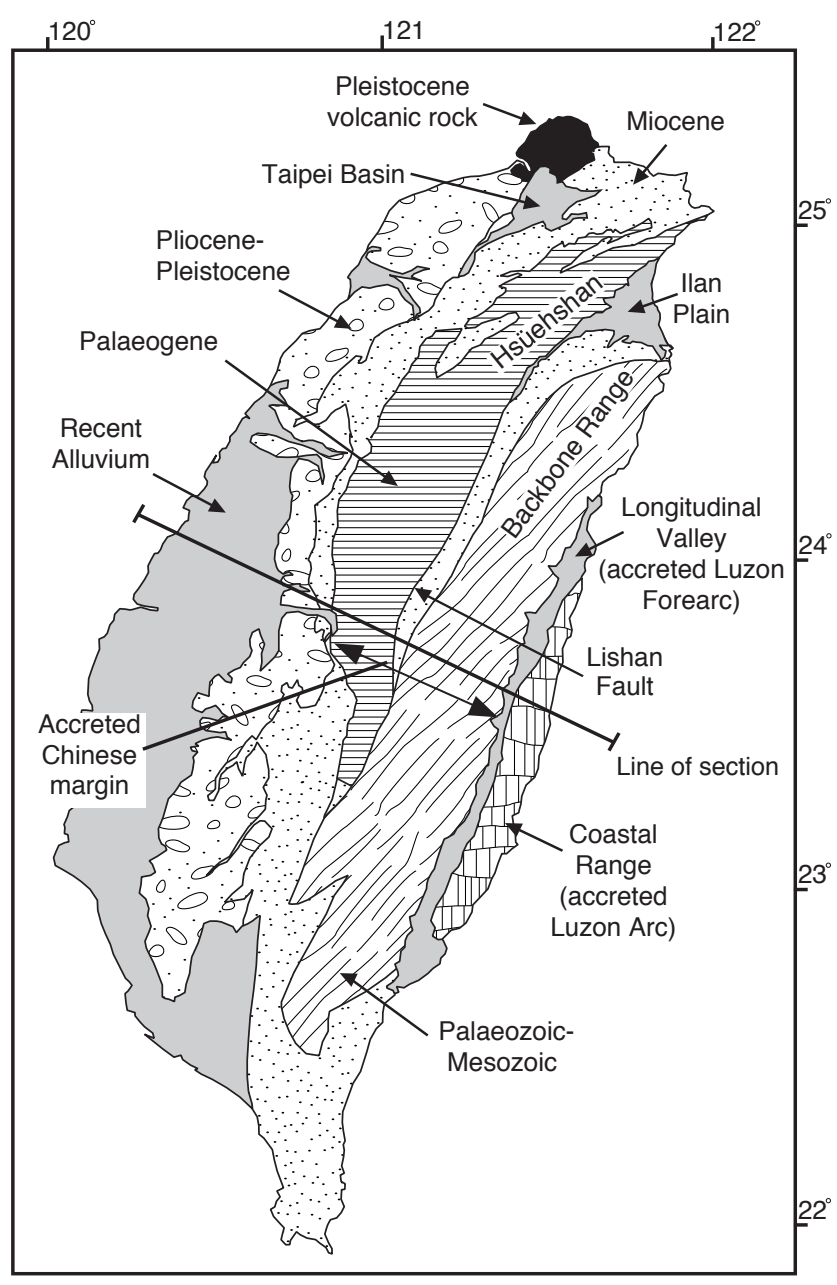

(B)

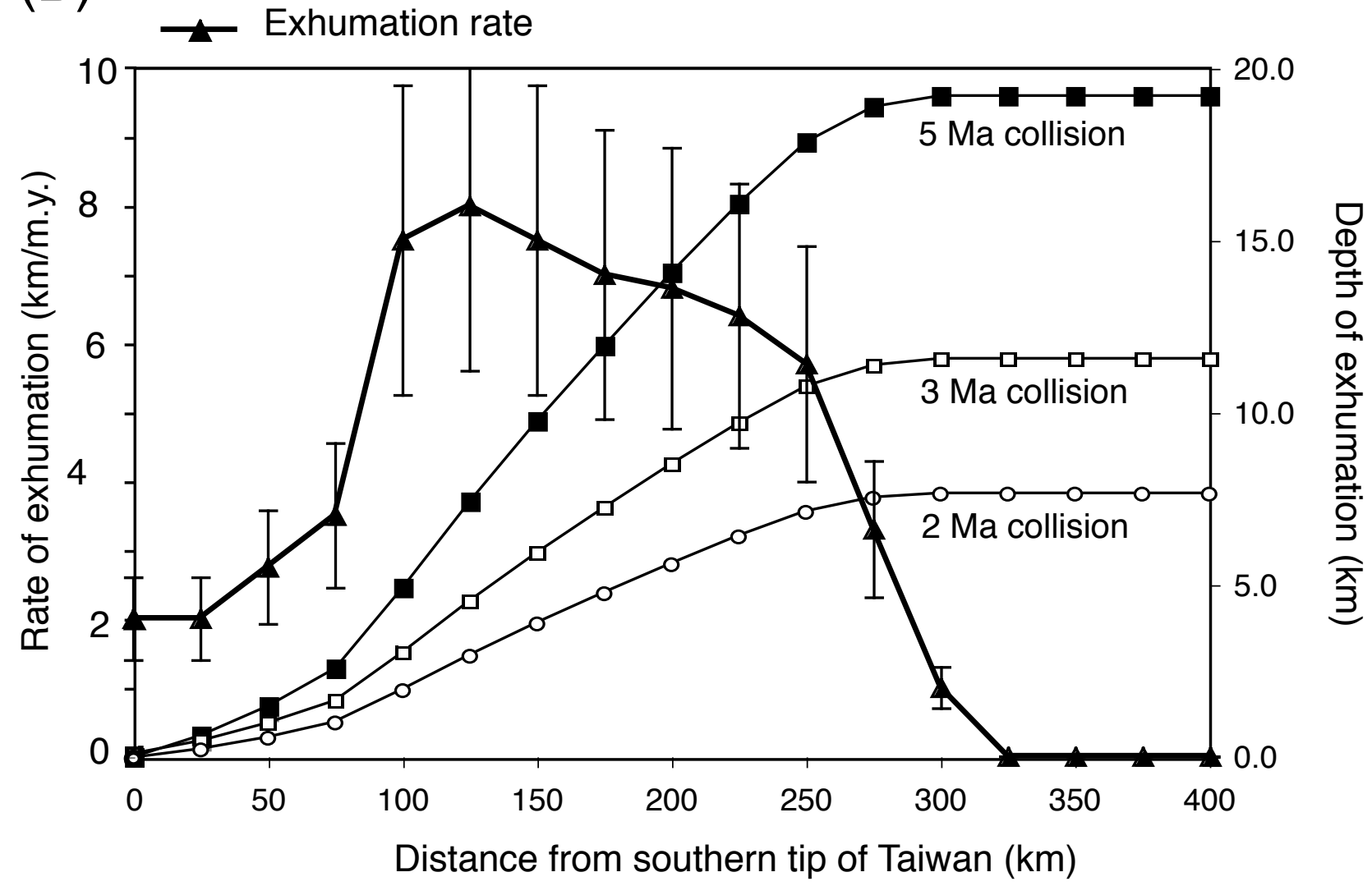

Figure 13

Clift et al. 


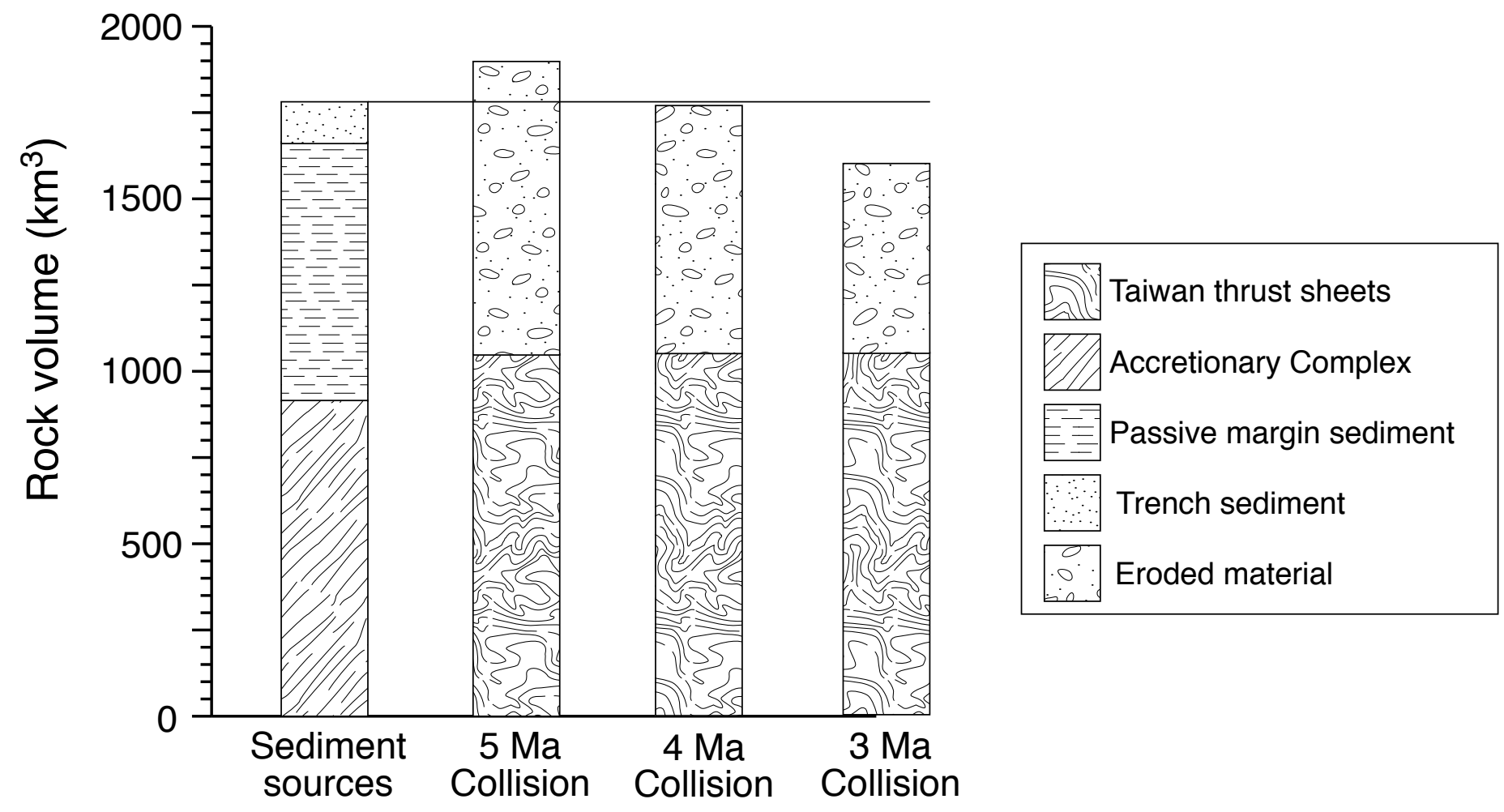

Figure 14

Clift et al. 


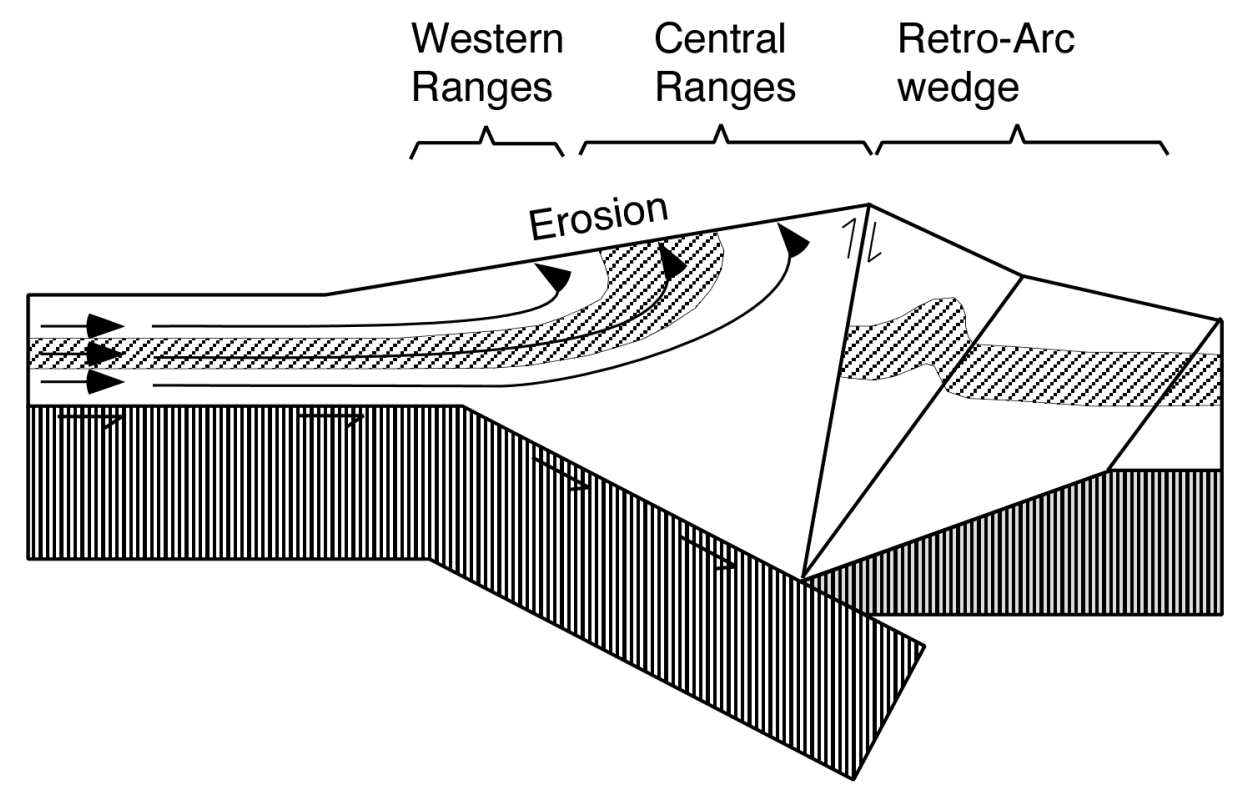

Figure 15

Clift et al. 


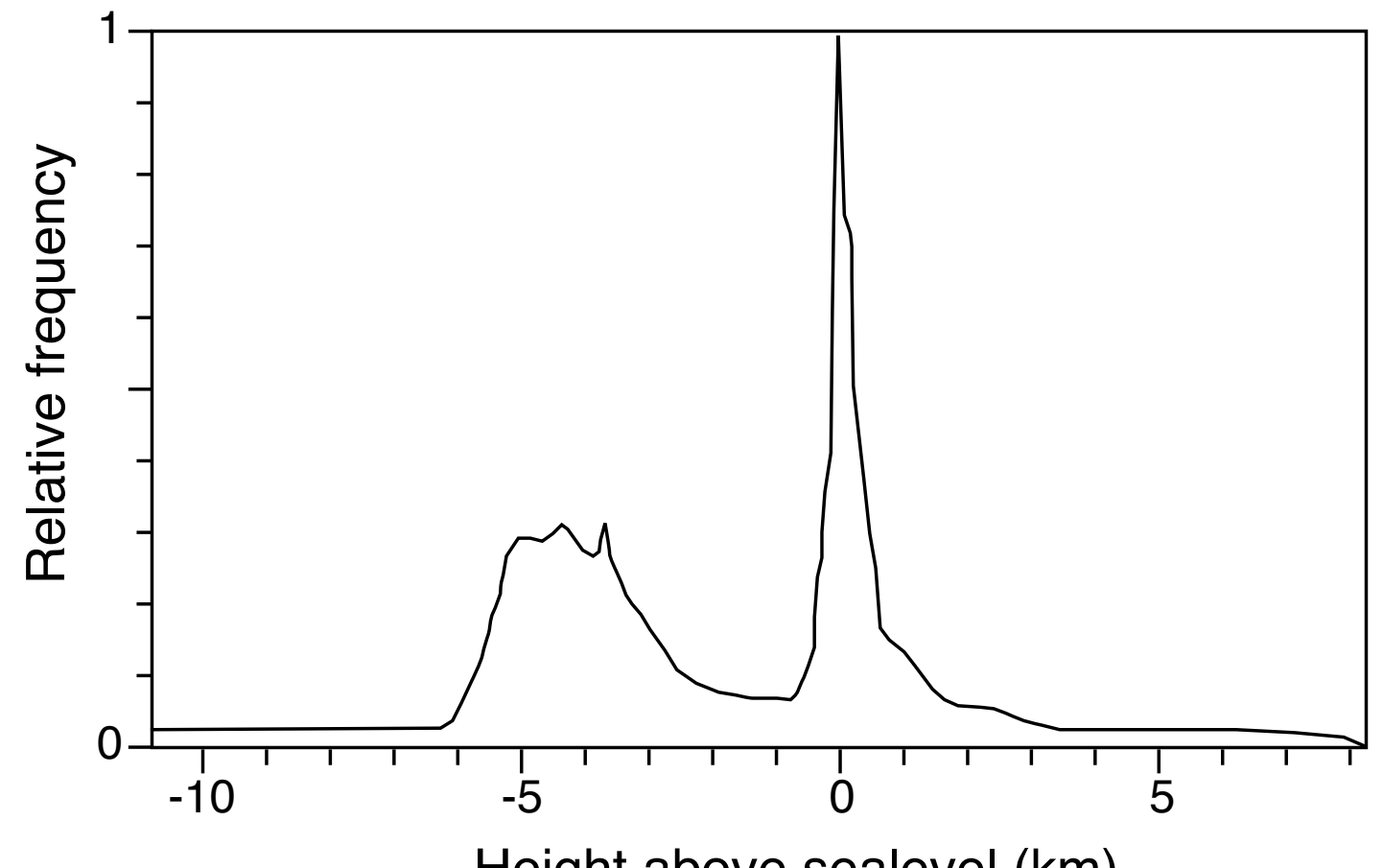

Height above sealevel $(\mathrm{km})$

Figure 16

Clift et al. 


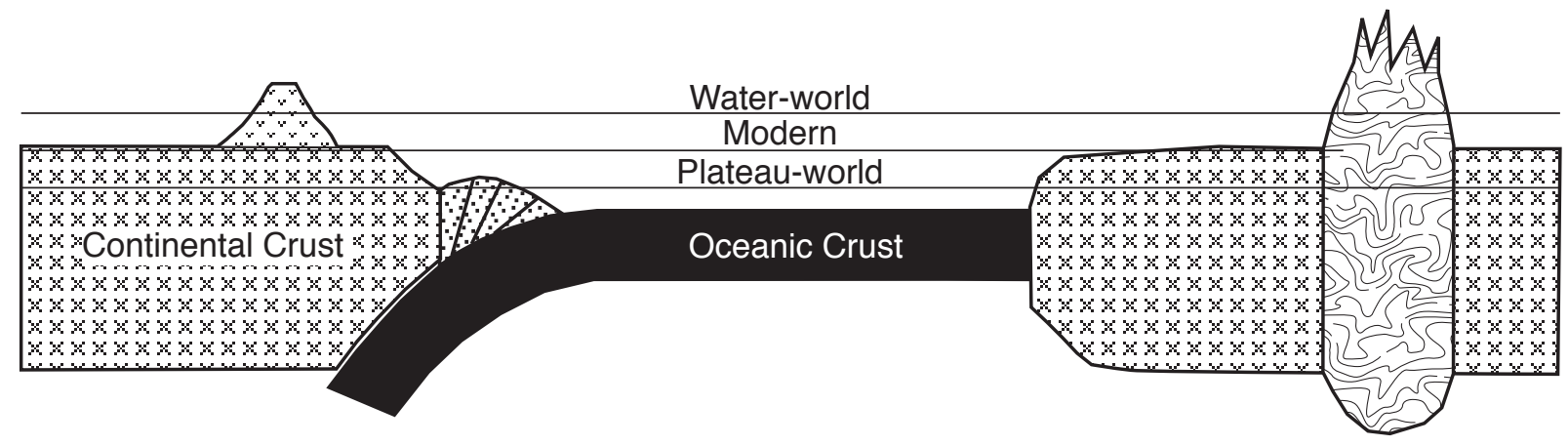

Figure 17

Clift et al. 


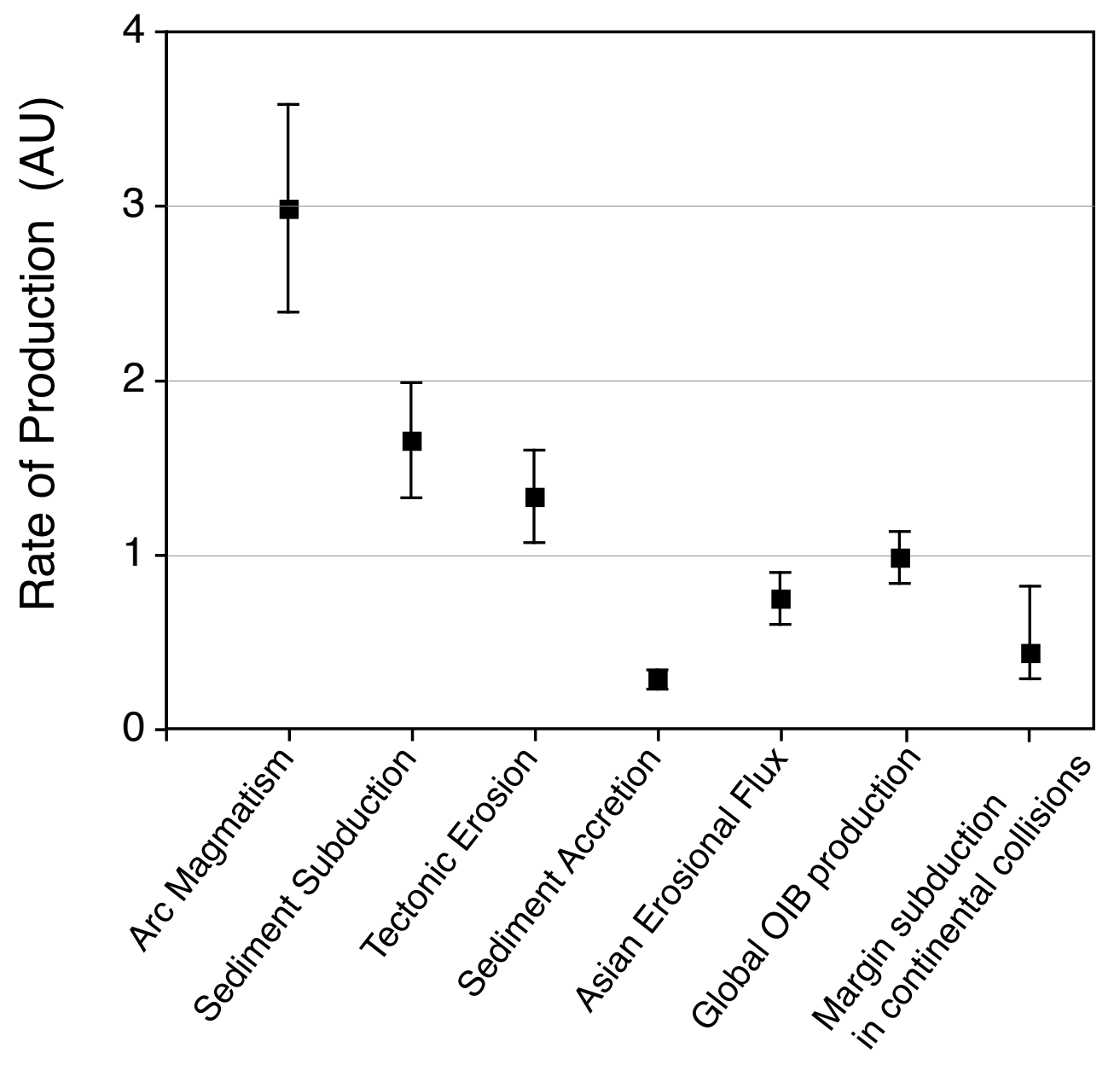

Figure 18

Clift et al. 


\begin{tabular}{|c|c|c|c|c|c|c|c|}
\hline Cenozoic Orogen & $\begin{array}{c}\text { Length of } \\
\text { subducted } \\
\text { margin }(\mathbf{k m}) \\
\end{array}$ & Margin type & $\begin{array}{l}\% \text { of } \\
\text { total }\end{array}$ & $\begin{array}{c}\text { Length of } \\
\text { margin } \\
(\mathbf{k m})\end{array}$ & $\begin{array}{c}\text { Width of } \\
\text { COT } \\
(\mathbf{k m})\end{array}$ & $\begin{array}{c}\text { Average } \\
\text { crustal } \\
\text { thickness } \\
(\mathbf{k m}) \\
\end{array}$ & $\begin{array}{c}\text { Volume } \\
\left(\mathbf{k m}^{3}\right) \\
\end{array}$ \\
\hline Alboran Sea & 1300 & Volcanic & 50 & 7875 & 50 & 18 & 7087500 \\
\hline Pyrenees & 450 & Non-volcanic & 50 & 7875 & 150 & 18 & 21262500 \\
\hline Alps-Appennines-Hellenides & 3000 & Total & & & & & 28350000 \\
\hline Turkey-Zagros & 3100 & & & & & & \\
\hline Himalaya & 2700 & & & & & & \\
\hline Taiwan-Ryukyu & 1100 & & & & & & \\
\hline Borneo & 1300 & & & & & & \\
\hline Australia-Papua New Guinea & 2800 & & & & & & \\
\hline Total & 15750 & & & & & & \\
\hline
\end{tabular}




\begin{tabular}{|c|c|c|c|c|c|c|c|c|c|c|c|}
\hline Arc & $\begin{array}{c}\text { Length } \\
(\mathrm{km})\end{array}$ & $\begin{array}{l}\text { Orthogonal } \\
\text { rate of } \\
\text { convergence } \\
(\mathrm{km} / \mathrm{my})\end{array}$ & $\begin{array}{c}\text { Trench } \\
\text { retreat rate } \\
(\mathrm{km} / \mathrm{my})\end{array}$ & $\begin{array}{c}\text { Trench } \\
\text { sediment } \\
\text { thickness } \\
(\mathrm{km})\end{array}$ & $\begin{array}{c}\begin{array}{c}\text { Rate of } \\
\text { sediment } \\
\text { delivery }\end{array} \\
\left(\mathrm{km}^{3} / \mathrm{m} . \mathrm{y} . / \mathrm{km}\right)\end{array}$ & $\begin{array}{c}\text { Rate of } \\
\text { forearc } \\
\text { erosion } \\
\left(\mathrm{km}^{3} / \mathrm{m} . \mathrm{y} . / \mathrm{km}\right)\end{array}$ & $\begin{array}{c}\text { Rate of } \\
\text { sediment } \\
\text { accretion } \\
\left(\mathrm{km}^{3} / \mathrm{m} . \mathrm{y} . / \mathrm{km}\right)\end{array}$ & $\begin{array}{c}\text { Rate of crustal } \\
\text { subduction } \\
\left(\mathrm{km}^{3} / \mathrm{m} . \mathrm{y} . / \mathrm{km}\right)\end{array}$ & $\begin{array}{l}\text { Efficiency } \\
\text { of sediment } \\
\text { accretion } \\
(\%)\end{array}$ & $\begin{array}{c}\text { Magmatic } \\
\text { Productivity } \\
\text { Rate } \\
\left(\mathrm{km}^{3} / \mathrm{m} . \mathrm{y} . / \mathrm{km}\right)\end{array}$ & $\begin{array}{l}\text { Net crustal } \\
\text { growth rate } \\
\left(\mathrm{km}^{3} / \mathrm{m} . \mathrm{y} . / \mathrm{km}\right. \\
)\end{array}$ \\
\hline \multicolumn{12}{|l|}{ Erosive Margins } \\
\hline North Chile & 2000 & 89 & 3.0 & 0.3 & 13 & 15 & & 28 & & 99 & 84 \\
\hline Peru & 2200 & 77 & 3.1 & 0.7 & 29 & 15 & & 44 & & 86 & 71 \\
\hline Ecuador-Colombia & 1100 & 63 & 3.0 & 0.6 & 20 & 15 & & 35 & & 71 & 56 \\
\hline Costa Rica & 450 & 80 & 3.0 & 0.4 & 17 & 105 & & 122 & & 89 & -16 \\
\hline Nicaragua & 275 & 78 & 2.0 & 0.3 & 12 & 64 & & 76 & & 86 & 22 \\
\hline Guatemala & 500 & 74 & 0.9 & 0.3 & 12 & 34 & & 46 & & 82 & 48 \\
\hline Mexico & 1700 & 68 & 1.0 & 0.6 & 22 & 40 & & 62 & & 75 & 35 \\
\hline Kurile & 1100 & 85 & 3.0 & 0.5 & 20 & 75 & & 95 & & 94 & 19 \\
\hline Kamchatka & 1100 & 80 & 3.0 & 0.8 & 36 & 120 & & 156 & & 89 & -31 \\
\hline NE Japan & 1000 & 100 & 3.0 & 0.8 & 45 & 120 & & 165 & & 111 & -9 \\
\hline Mariana & 1600 & 90 & 1.0 & 0.4 & 19 & 20 & & 39 & & 100 & 80 \\
\hline Izu-Bonin & 1300 & 89 & 2.0 & 0.4 & 19 & 40 & & 59 & & 99 & 59 \\
\hline Ryukyu & 1000 & 69 & 3.0 & 0.4 & 14 & 90 & & 104 & & 77 & -13 \\
\hline South Luzon & 400 & 90 & 1.5 & 0.4 & 19 & 48 & & 67 & & 100 & 52 \\
\hline Philippine & 1000 & 40 & 3.0 & 0.6 & 13 & 96 & & 109 & & 45 & -51 \\
\hline Tonga & 1500 & 110 & 3.8 & 0.4 & 23 & 76 & & 99 & & 122 & 46 \\
\hline Kermadec & 1250 & 68 & 1.5 & 0.4 & 14 & 30 & & 44 & & 75 & 45 \\
\hline Solomons & 2750 & 110 & 3.8 & 0.3 & 17 & 95 & & 112 & & 122 & 27 \\
\hline South Sandwich & 700 & 77 & 4.7 & 0.4 & 16 & 94 & & 110 & & 86 & -8 \\
\hline \multicolumn{12}{|l|}{ Accretionary Margins } \\
\hline South Chile & 2000 & 20 & & 3.2 & 43 & & 7 & 36 & 16 & 22 & 29 \\
\hline Lesser Antilles & 850 & 40 & & 4.5 & 137 & & 19 & 118 & 14 & 44 & 64 \\
\hline Oregon-Washington & 850 & 34 & & 2.2 & 48 & & 10 & 38 & 21 & 38 & 48 \\
\hline British Columbia & 550 & 38 & & 2.5 & 61 & & 10 & 51 & 16 & 42 & 52 \\
\hline Aleutians & 1500 & 61 & & 1.5 & 54 & & 4 & 50 & 7 & 68 & 72 \\
\hline Alaska & 2050 & 60 & & 2.5 & 96 & & 17 & 79 & 18 & 67 & 84 \\
\hline Taiwan-North Luzon & 700 & 30 & & 4.5 & 95 & & 25 & 70 & 26 & 33 & 58 \\
\hline SW Japan-Nankai & 900 & 39 & & 2.3 & 65 & & 24 & 41 & 37 & 44 & 68 \\
\hline Sumatra & 1800 & 52 & & 2.5 & 83 & & 11 & 72 & 13 & 58 & 69 \\
\hline Java & 2100 & 76 & & 1.2 & 54 & & 14 & 40 & 26 & 84 & 98 \\
\hline Burma-Andaman & 1800 & 27 & & 5.0 & 99 & & 27 & 71 & 28 & 31 & 58 \\
\hline Makran & 1000 & 38 & & 6.0 & 179 & & 29 & 150 & 16 & 42 & 71 \\
\hline Aegean & 1200 & 20 & & 8.0 & 131 & & 22 & 109 & 17 & 22 & 45 \\
\hline
\end{tabular}


Table 3

\begin{tabular}{l|c} 
& Rate $(\mathrm{AU})$ \\
\hline Arc magma production & 2.98 \\
Sediment subduction & 1.65 \\
Tectonic erosion & 1.33 \\
Subduction accretion & 0.28 \\
Total river discharge & 6.70 \\
Mainland Asian erosion & 0.75 \\
MORB production & 20.00 \\
OIB Production & 0.5 \\
Subduction of passive & \\
margins in orogens & 0.4
\end{tabular}

Clift et al. 
Table 4

Tectonic Unit

Volume $\left(\mathrm{km}^{3} / \mathrm{km}\right.$ of trench $)$

Taiwan thrust sheets

Sediment in Taiwan foreland

1076

250

Trench sediment in Luzon Trench

125

Accretionary prism offshore Luzon

825

Arc under Taiwan

2155

Luzon Arc igneous crust

2475

Ryukyu accretionary prism

210

Sediment in Okinawa Trough

Sediment on S China margin

300

750

Sediment eroded from Taiwan (5 Ma collision)

880

Sediment eroded from Taiwan (4 Ma collision)

720

Sediment eroded from Taiwan (3 Ma collision)

550

Clift et al. 


\begin{tabular}{l|cc} 
& $\begin{array}{c}\text { Eroded rock } \\
\left.\text { volume } \mathbf{( k m}^{\mathbf{3}}\right)\end{array}$ & $\begin{array}{c}\text { Percentage } \\
\text { of total }\end{array}$ \\
\hline Basin & 10271159 & 36.8 \\
Bengal Fan & 4108463 & 14.7 \\
Indus Fan & 3200000 & 11.5 \\
Sediment subducted in Andaman Trench & 2042711 & 7.3 \\
Himalayan Foreland Basin & 1900000 & 6.8 \\
Central Asian Basins (Tarim, Junggar, & 1472473 & 5.3 \\
Irrawaddy Fan & 1300000 & 4.7 \\
Sediment subducted in Makran & 451931 & 1.6 \\
Song Hong/Yinggehai Basin & 389972 & 1.4 \\
Katawaz Basin & 389972 & 1.4 \\
Sulaiman/Kirthar Ranges & 345111 & 1.2 \\
East China Sea & 328677 & 1.2 \\
Pearl River Mouth Basin & 315530 & 1.1 \\
Malay Basin & 287592 & 1.0 \\
Nam Con Son Basin & 246508 & 0.9 \\
SE Hainan Basin (Qiongdongnan Basin) & 237697 & 0.9 \\
Burma Basin & 177486 & 0.6 \\
Mekong/Cuu Long Basin & 129991 & 0.5 \\
Indo-Burma Ranges & 123254 & 0.4 \\
Bohai Gulf & 65735 & 0.2 \\
Pengyu Basin & 65078 & 0.2 \\
Pattani Trough & 36976 & 0.1 \\
West Natuna Basin & 8124 & 0.0 \\
Hanoi Basin & $\mathbf{2 7 8 9 4 4 4 2}$ & \\
\hline Total eroded & & \\
& & \\
& & \\
& &
\end{tabular}


Table 6

\begin{tabular}{l|cc} 
& $\begin{array}{c}\text { Rate of Erosion } \\
\left(\mathrm{km}^{3} / \mathrm{m} . \mathrm{y} .\right)\end{array}$ & $\begin{array}{c}\text { Armstrong } \\
\text { Units }\end{array}$ \\
\hline Average erosion rate since 50 Ma & 557889 & 0.56 \\
Average erosion rate since 33 Ma & 845286 & 0.85 \\
Average erosion rate since 22 Ma & 1267929 & 1.27 \\
& & \\
Time required to erode modern Tibet at 50 Ma rate & 220 & \\
Time required to erode modern Tibet at 33 Ma rate & 145 & \\
Time required to erode modern Tibet at 22 Ma rate & 97
\end{tabular}

Clift et al. 